\title{
Metabolic constituents of grapevine and grape-derived products
}

\author{
Kashif Ali • Federica Maltese • \\ Young Hae Choi $\cdot$ Robert Verpoorte
}

Received: 5 March 2009/ Accepted: 22 October 2009/Published online: 8 November 2009

(C) The Author(s) 2009. This article is published with open access at Springerlink.com

\begin{abstract}
The numerous uses of the grapevine fruit, especially for wine and beverages, have made it one of the most important plants worldwide. The phytochemistry of grapevine is rich in a wide range of compounds. Many of them are renowned for their numerous medicinal uses. The production of grapevine metabolites is highly conditioned by many factors like environment or pathogen attack. Some grapevine phytoalexins have gained a great deal of attention due to their antimicrobial activities, being also involved in the induction of resistance in grapevine against those pathogens. Meanwhile grapevine biotechnology is still evolving, thanks to the technological advance of modern science, and biotechnologists are making huge efforts to produce grapevine cultivars of desired characteristics. In this paper, important metabolites from grapevine and grape derived products like wine will be reviewed with their health promoting effects and their role against certain stress factors in grapevine physiology.
\end{abstract}

Keywords Grapevine - Medicinal importance . Phytochemistry $\cdot$ Resistance

K. Ali · F. Maltese · Y. H. Choi $(\square) \cdot$ R. Verpoorte Division of Pharmacognosy, Section Metabolomics, Institute of Biology, Leiden University, Einsteinweg 55, P.O. Box 9502, 2333 CC Leiden, The Netherlands e-mail: y.choi@chem.leidenuniv.nl

\section{Introduction}

Grapevine (Vitis spp.) is globally one of the most important fruit species due to the numerous uses of its fruit in the production of wine, grape juice and other foods. It has a connection with an ancient historical development of human culture. In the earliest writings and archives associated to all sorts of agricultural and religious activities, grapevine and its products were given a significant place (Thomas et al. 1993). The oldest records of the use of grapevine products by humans dated back to 35002900 B.C. (Bowers et al. 1999). Among the Vitis species, Vitis vinifera is currently the most cultivated fruit crop around the world because of its use in wine production (Lodhi and Reisch 1995).

The grapevine has been easily cultivated and across the world gives rise up to eight million hectares of vineyards (Vivier and Pretorius 2000). Up to now $V$. vinifera has reached all continents but is successfully cultivated only in temperate climate regions with sufficient rain, warm and dry summers and relatively mild winters. The Vitaceae family consists of almost one thousand species, grouped in seventeen genera. Grapevines are classified in the Vitis genus and it is generally accepted that the most cultivated $V$. vinifera comprises up to 5,000 true cultivars, used in wine, table (fresh fruit) and dried grape manufacturing around the world. Improvements to these cultivars initially relied largely on random selections of natural mutations which 
resulted in enhanced cultivation or improvement in some aspects of fruits and/or wine quality. This was later followed by more directed clonal selection schemes (Bowers et al. 1999).

The quality of grapevine, as with most plants, mainly depends on its metabolites. The production of these metabolites is especially sensitive to external conditions. In particular, the chemical diversity of grapevine is mostly affected by secondary metabolites. These secondary metabolites consist of a wide array of species-specific chemicals and belong to different phytochemical groups such as alkaloids, terpenes, antibiotics, volatile oils, resins, cardiac glycosides, tannins, sterols, saponins and phenolics, many of which have proved to be of great value to the pharmaceutical, agrochemical, food and fragrance industries (Zhang et al. 2005). In general, secondary metabolites are known to play key physiological functions in plants including their adaptation to the environment (Lewinsohn et al. 2001), acquired resistance to pests and diseases, pollinator attractant capacity and the building of symbiotic relations with microorganisms (Harborne 2001). They are also very often crucial in the determination of the quality of food attributes (color, taste, and aroma), and colors and pigments of ornamental plants (Dixon 2001; Iriti and Faoro 2006).

This review attempts to present detailed features of grapevine chemistry including primary and secondary metabolites and the biological activities associated to these chemical constituents. A detailed account of grapevine diseases and their resistance to them is also presented, followed by a brief discussion on grape biotechnology and its prospects. Grape seed oil, an important grape-derived product, is not included in this review. The nutritional highlights of the grape seed oil have been recently reviewed by Bertrand (2008).

\section{Overview on phytochemistry of grapes and wine}

Plant metabolism is mainly divided into two types, i.e. primary and secondary metabolism. Plant primary and secondary metabolites are known to perform completely different tasks in plants. A "primary metabolite" is directly involved in normal growth, development, and reproduction of plant species while a "secondary metabolite" is not directly involved in those processes, but usually has important ecological functions like defenses against predators, parasites and diseases, for interspecies competition, and to facilitate the reproductive processes (coloring agents, attractive smells, etc.). Many of these primary and secondary metabolites from plants are famous for their beneficial effects on human health.

The phytochemical composition of grapevine includes a great variety of known bioactive compounds such as vitamin E, flavonoids, linoleic acid and procyanidins (also known as condensed tannins, and oligomeric proanthocyanidins) the last of which are highly concentrated in grape seeds (Yilmaz and Toledo 2004). These health-affecting compounds can also be found in lower concentrations in grape skin. Procyanidins are found in grape juice and wine, although in lower concentrations. Resveratrol is another very important example of grape's health promoting compounds. Among other beneficial effects, the active compounds in grape seed have been proved to have powerful antioxidant properties (Yilmaz and Toledo 2004). Antioxidants are substances that may help eliminate free radicals which are believed to contribute in aging process as well as in the development of a number of health problems like heart diseases and cancer. Antioxidants found in grape seeds can neutralize free radicals and may reduce or even help prevent some of the damage caused by them. Resveratrol (a key component in grapevine phytochemistry) has gained much popularity as an antioxidant supplement (Sovak 2001). Figure 1 shows the biosynthetic pathways of important phytochemicals from grapevines.

The chemical composition of grapes and wine has been intensely studied in the recent decades and the number of compounds identified increased exponentially since the development of different analytical techniques such as gas chromatography (GC), high performance liquid chromatography (HPLC) and high performance thin layer chromatography (HPTLC) coupled with nuclear magnetic resonance (NMR) and mass spectrometry (MS) (Brun et al. 1986).

The study of the chemical composition of wine has so far allowed the identification of more than 500 compounds of which 160 compounds were esters. The concentration of these compounds ranges from $10^{-1}$ to $10^{-6} \mathrm{mg} / \mathrm{l}$. Even at these concentrations many of the individual compounds are likely to play a very important role in the human taste perception. 


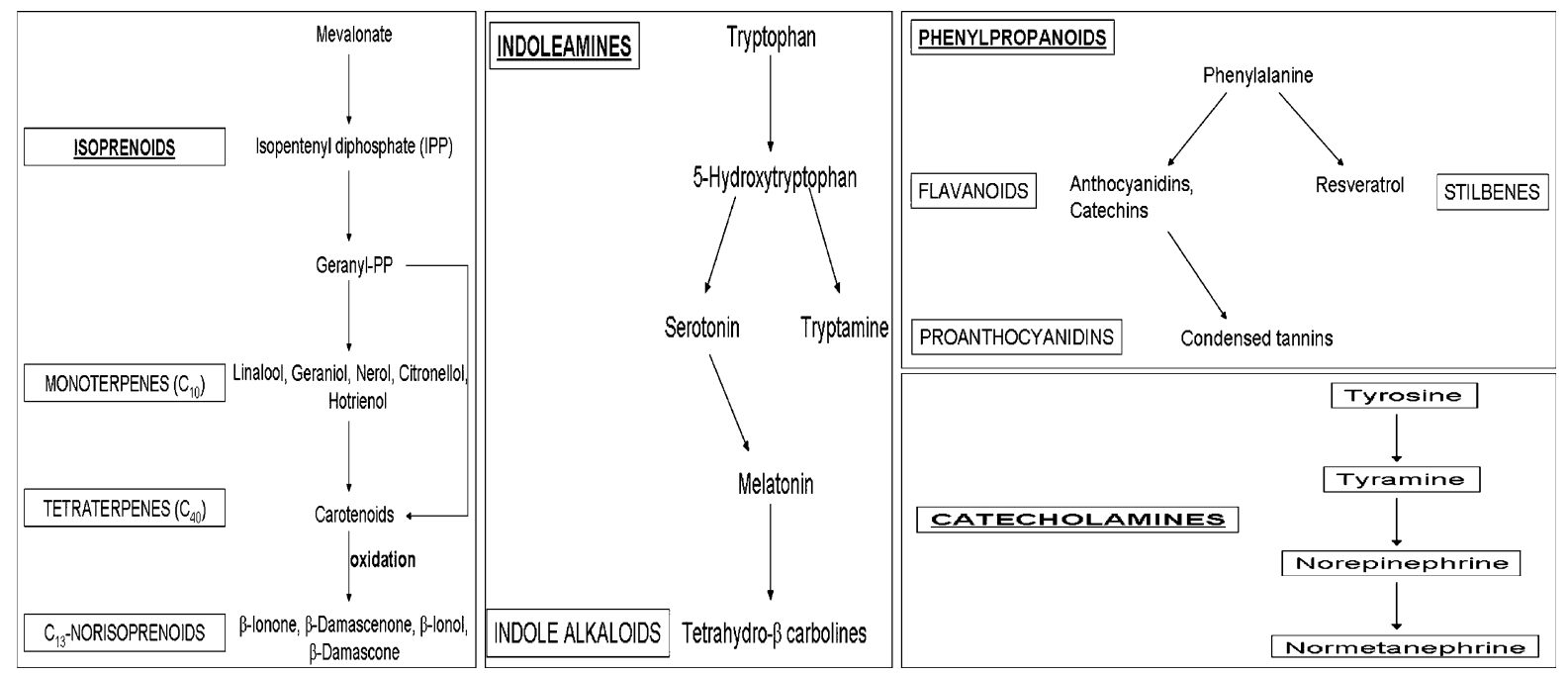

Fig. 1 Schematic diagram of the synthesis of grapevine phytochemicals

The carbonyls, phenols, lactones, terpenes, acetals, hydrocarbons, sulfur, and nitrogen compounds, although present in very low concentrations, contribute to the fragrance of wine. However, the taste and mouth-feel sensations are primarily due to compounds like water, ethanol, organic acids, amino acids, sugars, and glycerol.

\section{Primary metabolites in grapes and wine}

Sugars and amino acids

Glucose and fructose are the principal grape sugars while sucrose and other sugars are rarely found in $V$. vinifera grapes. Cultivars other than $V$. vinifera may contain up to a $10 \%$ of sucrose. Amount of sugars in $V$. vinifera can be affected by cultivar type, maturity and health of the berries (Crippen and Morrison 1986). High sugar concentrations can also result in the increase of the volatility of aromatic compounds. Generally, sweetness is detected at levels higher than $1 \%(\mathrm{w} / \mathrm{v})$ of overall sugars, and this is influenced by other constituents such as ethanol, acids, and tannins.

The amino acids contribute to wine aroma, taste, and appearance (Hernandez-Orte et al. 2003). Carrying out studies of partial least-squares regression models, Hernandez-Orte et al. (2002) found that amino acid composition accounts for a high proportion of the variance in the volatile composition.
Moreover, the composition of the amino acids in the wine has an influence on aromas during the maturing process (Escudero et al. 2000). In the wineries, obtaining young wines with fruity aromas is now gaining much interest. In order to improve the kinetics of wine fermentation, activators are usually added, mainly ammonium salts, also auxiliaries to avoid stuck and sluggish fermentations (Bisson 1999; Blateyron and Sablayrolles 2001). Daily-based research is carried out into new additives and therefore it is interesting to know how the addition of nitrogen sources affects amino acid uptake by the yeast and how the addition affects the synthesis of aroma compounds. The activators are metabolized by the yeasts and modify the consumption of amino acids and ammonium in the juice thus causing a variation in the wine aroma. As occurs with esters, the pool of intracellular nitrogen regulates the formation of higher alcohols (Large 1986).

Biogenic amines

Biogenic amines (BA) in wines are produced from the free amino acids by microbial decarboxylation. They can be originated from the different wine making processes or from the grape berries and have unpleasant effects at high concentrations and caused a health risk to sensitive individuals (Gardini et al. 2005). Studies on BA showed that yeasts not appear to be responsible for the production of BAs in 
commercial red wines (Marcobal et al. 2006). The wine contamination with BAs mostly occurred during natural or spontaneous malolactic fermentation by lactic acid bacteria present in low population in healthy grapes (Herbert et al. 2005; Landete et al. 2005). Although there are no legal limits for BAs but some countries, like Austria and Switzerland, have their own suggestions. The export of wines to those countries could be affected by the higher levels of BAs, making BAs a potential economic threat.

\section{Polysaccharides}

In comparison with other macromolecular fractions, wine polysaccharides have been less studied. Some of their properties were determined (Riou et al. 2002) along with the characterization of their structures (Vidal et al. 2000) during the past decades. Polysaccharides are generally low in final wine products, being partially water soluble and extracted into the juice during crushing and pressing. The effects of polysaccharides in wines are probably direct, i.e. 'mellowness' or indirect by modulating astringency. The main polysaccharides in wine include type II arabinogalactan-proteins and rhamnogalacturonans (from grapes) and mannoproteins (from yeast) (Pellerin et al. 1995, 1996).

\section{Alcohols}

According to Fraile et al. (2000), the formation of different alcohols takes place at the end of the fermentation, when most of the amino acids have been consumed, whereas, according to Rapp and Versini (1991), this synthesis occurs at the same time as ethanol production. Ethanol is the most abundant and important alcohol in wine. Ethanol concentration in wine generally ranges from 10 to $13 \mathrm{ml} / 100 \mathrm{ml}$, depending mainly on sugar content and lesser on temperature and yeast strain. Ethanol is crucial to the stability, aging, and sensory properties of wine. It also influences the type and amount of aromatic compounds produced by affecting the metabolic activity of yeast. The dissolving action of ethanol is also probably involved in the reduction of the evaporation of aromatic compounds during fermentation (Williams and Rosser 1981). Moreover, it is also involved in the production of acetals by reacting with the aldehydes.
Methanol is also present in wines in fairly large amounts (0.1-0.2 g/l) (Jackson 2000). In wines methanol is formed by the degradation of pectic substances, present in crushed grapes, by enzyme action (Ribereau-Gayon et al. 2000). The methanol content in wines is dependent on number of factors like the variety and condition, maceration treatment, fermentation temperature, and pectolytic enzyme treatment. The in vivo oxidation of methanol produces formaldehyde and formic acid which are toxic to the central nervous system. Due to this methanol content is one of the critical control point parameters which should be controlled during the alcoholic fermentation stage to produce wine safe for human consumption (Kourtis and Arvanitoyannis 2001).

Other potentially significant higher alcohols in wine are n-propanol, 2-methyl-1-propanol, 2-methyl-1butanol, and 3-methyl-1-butanol (Rapp and Mandery 1986). The higher alcohols are produced as a by-product of yeast fermentation and their concentration is markedly influenced by vinification practices such as temperature, presence of oxygen, suspended solids and yeast strain (Sponholz 1988). Higher alcohols may produced by deamination of the amino acids and grapederived aldehydes, and by the denitrification of amino acids (Chen 1978).

Organic acids

In grape juice and wine, organic acids composition is very important as it highly influences the organoleptic properties, microbiologic control and a parameter of critical control in wine stabilization. The processes like alcoholic fermentation, malolactic fermentation, and oxidation of ethanol are involved in the production of these compounds or they may directly come from grapes. Tartaric and malic acids are the major organic acids in grape juice while it also contains succinic and citric acid in low amounts. Wine contains both volatile and fixed acids. Volatile acids, principally acetic acid, can be readily removed by reverse osmosis. The content of fixed acids such as tartaric, malic, and citric acid (from grapes) along with lactic, succinic, oxalic, fumaric, and citric acid (from fermentation process) influences the $\mathrm{pH}$ of wine (Singleton 1982). Also small amounts of different acids like galacturonic, citramalic, pyruvic acid, and ketoglutaric acid, etc. are there (Castellari et al. 2000). 


\section{Secondary metabolites in grapes and wine}

Phenolics

Phenolics are a large and complex group of metabolites particularly contributing to the characteristics of grapes and red wines. Phenolic compounds are ubiquitous and known to contribute to pigmentation of different organs along with their role against different biotic and abiotic stresses. A large range of structures has been shown by phenolic compounds, hence properties as well. Different properties of wine like appearance, taste, mouth-feel, fragrance, and antimicrobial activity can be affected by phenolics and related compound (Kennedy 2008). Grapevine phenolics may arise from the fruit (skins and seeds) and vine stems, or may be products of yeast metabolism. Figure 2 shows structures of some important phenolic compounds isolated from the grape seeds extracts. The concentration of phenolics
Fig. 2 Structures of major polyphenols identified in grape seed extract<smiles>O=C(O)c1cc(O)c(O)c(O)c1</smiles>

Gallic acid<smiles>[R7][C@H]1Cc2c(O)cc(O)cc2O[C@H]1c1ccc(O)c(O)c1</smiles>

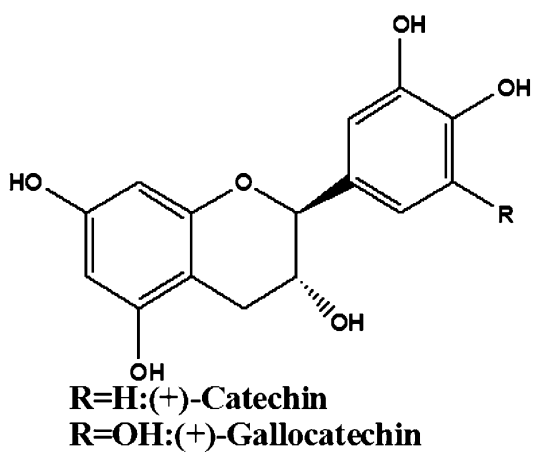<smiles>[R]Oc1cc(O)cc2c1C[C@H](O)[C@H](c1cc([R])c(O)c(O)c1)O2</smiles>

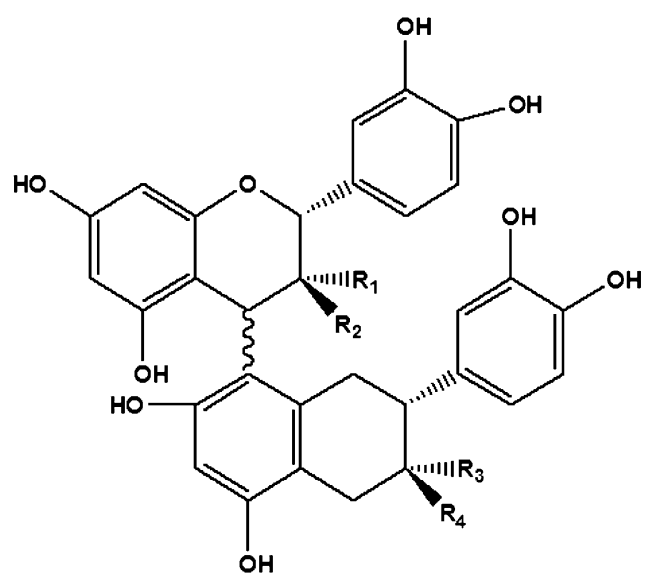

Proanthocyanidin B1: R1 $=\mathbf{O H}, \mathbf{R 2}=\mathrm{H}, \mathbf{R 3}=\mathrm{H}, \mathrm{R} 4=\mathrm{OH}$

Proanthocyanidin B2: R1 $=\mathrm{OH}, \mathrm{R2}=\mathrm{H}, \mathrm{R3}=\mathrm{OH}, \mathrm{R} 4=\mathrm{H}$

Proanthocyanidin B3: R1 $=\mathrm{H}, \mathrm{R} 2=\mathrm{OH}, \mathrm{R3}=\mathrm{H}, \mathrm{R} 4=\mathrm{OH}$

Proanthocyanidin B4: R1 $=\mathrm{H}, \mathrm{R2}=\mathrm{OH}, \mathrm{R3}=\mathrm{OH}, \mathrm{R4}=\mathrm{H}$ 


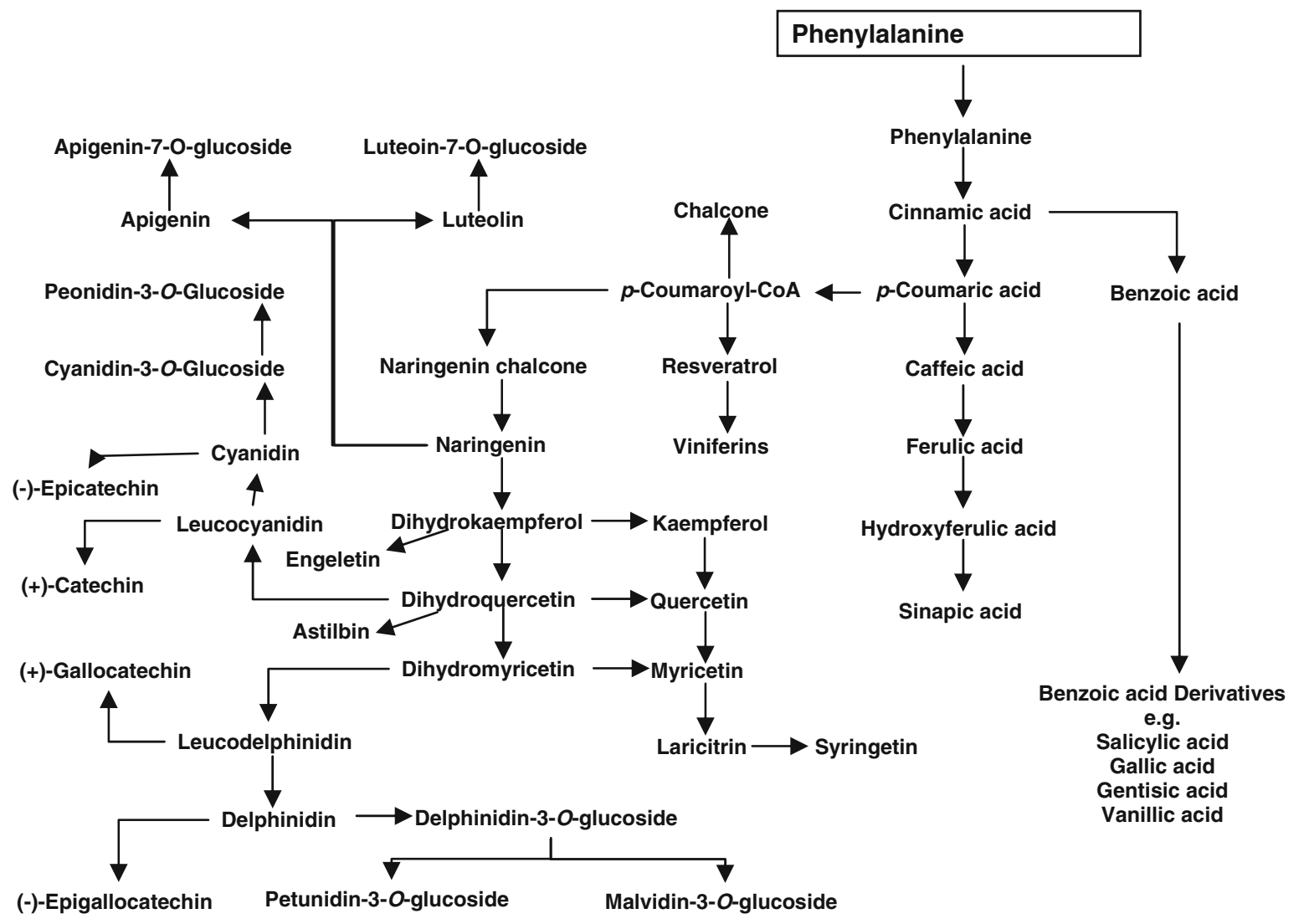

Fig. 3 Biosynthetic pathway from phenylalanine to different classes of phenolics found in grapevine and wine

in wine increases during fermentation but begins to fall as they bind and precipitate with proteins and yeast hulls. During fining and maturation, the phenolics concentration continues to decrease, suffering a dramatic fall during the aging stage. The three primary phenol groups that occur in grapes and wine are simple phenolics, flavonoids, and stilbenoids. The schematic biosyntheses of these three groups are shown in Fig. 3.

Simple phenolics and phenylpropanoids

Simple phenolics of grape origin are initially synthesized from phenylalanine (Hrazdina et al. 1984), whereas those of yeast origin are derived from acetic acid (Packter 1980). Simple phenolics are derivatives of hydroxycinnamic acids (HCA) and hydroxybenzoic acids (HBA). Primarily, they are stored in cell vacuoles of grape cells and can easily be released by crushing. Common hydroxycinnamic acids are $p$-coumaric acid, caffeic acid, sinapic acid, and ferulic acid. In wine esterified form of HCA with tartaric acid is more common than free HCA. The caftaric acid (caffeic acid conjugated with tartaric acid) is predominant (up to $50 \%$ ) of the total HCA. Since the concentration of HCA depend on factors like grape variety, growing conditions, climate, etc., different studies shows different concentrations. Compounds like $p$-coutaric acid ( $p$-coumaric acid conjugated with tartaric acid) and fertaric acid (ferulic acid conjugated with tartaric acid) are found in the concentrations of 55 and $16 \mathrm{mg} / \mathrm{l}$, respectively (Ricardo-Da-Silva et al. 1993). Derivatives of HCA like ethyl esters of caffeic and coumaric acid along with ethyl esters and diethyl esters of caftaric acid were also reported (Baderschneider and Winterhalter 2001). Evidence of glucosides like 4- $O$ glucosides of ferulic and coumaric acids (both $\mathrm{cis}$ - and trans-forms), glucosides of caffeic, coumaric, ferulic, and sinapic acids have been shown by some studies (Cooper and Marshall 2001; Monagas et al. 2005; Baderschneider and Winterhalter 2001). Previous reports of NMR characterization showed cis-isomers 
of coumaric and coutaric acids in Chardonnay grape pomace and Riesling wine (Baderschneider and Winterhalter 2001). The hydroxycinnamic esters are more concentrated (2- to 100-fold) in grape skin than in pulp. Differences in the total amount and proportion (Cheynier et al. 1986) have been reported based on the varietal differences. In addition, HCAs are also important constituents of acylated anthocyanins. The relation of acetylated and coumaroylated anthocyanins can be used in the authenticity control of red wine.

When compared with HCA, wines have lower levels of hydroxybenzoic acids (HBAs) and their derivatives. The most common HBAs are gallic acid, gentisic acid, protocatechuic acid, and p-hydroxybenzoic acid, which are mainly found in their free form (Pozo-Bayon et al. 2003; Vanhoenacker et al. 2001). Hydroxybenzoic acids are mostly represented by gallic acid, which is found free as well as acyl substituent of flavan-3-ols. Two forms of gallic acid, i.e. 3-O- $\beta$-glucopyranoside and 4-O- $\beta$-glucopyranoside, have been reported in grape (Lu and Foo 1999). In wine the level of gallic acid has been shown by many studies (Pozo-Bayon et al. 2003; Pena-Neira et al. 2000; Sladkovsky et al. 2004) that gallic acid is ranging from 0.3 to $4.8 \mathrm{mg} / \mathrm{l}$. Other benzoic acids such as protocatechuic, vanillic, and syringic acids are reported in Riesling wine from Germany (Baderschneider and Winterhalter 2001). Several derivatives of HBA were also identified including the ethyl esters of vanillic and $p$-hydroxybenzoic acid, methyl esters of vanillic and protocatechuic acid, ethyl esters of protocatechuic acid, the glucose ester of vanillic acid, from German Riesling wine (Baderschneider and Winterhalter 2001).

\section{Flavonoids}

Flavonoids are found primarily in the skins and seeds of the grapevine fruit. Flavonoids can be further divided into several sub-groups like flavones, flavonols, dihydroflavanols, flavanols, and anthocyanidins, with the same skeleton but different oxidation state of their central pyran ring. The most common flavonoids in wine are flavonols, catechins (flavan-3-ols), and anthocyanins.

Flavonoids are synthesized from the combination of the shikimic and polyketide pathway. Polymerization of polyhydroxy flavan 3-ol units, $(+)$-catechin and (-)-epicatechin, and their gallate esters produces oligomers and polymers called proanthocyanidins (often referred to as procyanidins). Even though procyanidins occur primarily as dimers in grapes (Kennedy 2008), they tend to be polymerized and predominate in wine as condensed tannins (mid-size procyanidin polymers containing three to five subunits). In some cultivars, structural differences exist among skin, stem, and seed procyanidins. Also, there are considerable differences in types and concentrations between cultivars (Boselli et al. 2004). In grape seeds and skin, about twenty procyanidin dimmers and trimers have been identified (Fulcrand et al. 1999). Seeds contained procyanidin of catechins, epicatechin, and epicatechin gallate units while grape skin and wine showed procyanidins mostly based on epicatechin and epigallotcatechin units (De PascualTeresea et al. 2000). The total amount of procyanidins is reported to vary from 1.7 to $4.4 \mathrm{~g} / \mathrm{kg}$ of berries in skin, 1.1 to $6.4 \mathrm{~g} / \mathrm{kg}$ in seeds, and 0.2 to $1 \mathrm{~g} / \mathrm{kg}$ in pulp (Mane et al. 2007).

Anthocyanins, which are responsible for the red or pink color in grape berries, belong to the flavonoid family. They are glycosylated derivatives and their parallel aglycones are known as anthocyanidins. In $V$. vinifera, 3-monoglucosides are the major anthocyanins where glucose can be acylated by acetic, p-coumaric, and caffeic acid (Alcalde-Eon et al. 2006; Vidal et al. 2004). Some additional anthocyanins, like 3-caffeoylglucosides of peonidin, cyanidin and delphinidin, have also been reported in grapes using HPLC-MS (Vidal et al. 2004). The anthocyanin profiling can be use for the chemotaxonomic classification as the total amounts (from $500 \mathrm{mg} / \mathrm{kg}$ to $3 \mathrm{~g} / \mathrm{kg}$ of berries) and proportions of the various anthocyanins are the characteristic of each variety (Mattivi et al. 2006). Grape anthocyanin composition depends not only on the maturity but also different vine growing parameters like soil and climate together with practices such as pruning, fertilization, or watering (González-Neves et al. 2002). The accumulation of anthocyanins starts at the Veraison stage with occasional decrease towards the end of Ripe stage, especially in hot climates (Fournand et al. 2006).

In wine, apart from the anthocyanins, other class of compounds has been evolved known as pyranoanthocyanins. They are basically derived from anthocyanins having an additional pyran ring attached to position 4 and 5 of anthocyanin. These pyranoanthocyanins, e.g. vitisin A and B, varied in concentration 
at the different stages of wine (Asenstorfer et al. 2003). Pyranoanthocyanins are found more resistant against color loss due to sulfites and $\mathrm{pH}$ variation (Hakansson et al. 2003). The contribution of the pyranoanthocyanins in the color of red wine has been estimated by number of studies but resulted with different conclusions (Alcalde-Eon et al. 2006; Schwarz et al. 2003; Boido et al. 2006) which might be due to the wine type and the way to calculate the pigments. A particular type of pyranoanthocyanins derivatives are vinylpyranoanthocyanin-flavanol pigment, also known as Portisins (Mateus et al. 2004) as they isolated from the Port wine. These pigments have increased stability towards sulfites and $\mathrm{pH}$-induced color loss (Oliveira et al. 2006). The formation of this new class of pigment involves pyranoanthocyanins and vinyl-flavanols, represents an evolution in the wine pigments having pyranoanthocyanins as a main precursor.

Flavonols are also reported in grape berries in the form of 3-O-glycoside of quercetin, myricetin, kaempferol, isorhamnetin, laricitrin, and syringetin, both in red and white cultivars (Mattivi et al. 2006; Talcott and Lee 2002). Mostly 3-O-glucoside and 3$O$-glucuronide of flavanols are present on grapes but other mono and diglycosides are also reported present in lower amounts (Downey et al. 2003). Both grape and wine have also been reported for the presence of dihydroflavonols like astilbin and engeletin (Guebaila et al. 2006).

\section{Stilbenoids}

Stilbenoids (1,2-diarylethenes) are another class of phenolic compounds (non flavonoids) belonging to the phenolic group and attracted great interest because of their potential health valuable effects (Guebaila et al. 2006). Stilbenes are essentially located in grape skin (Creasy and Coffee 1988; Roggero and Garcia-Parrilla 1995) but also reported in grape seeds (Sun et al. 2006) and grape stem (Bavaresco et al. 1997). Grapes and red wine are two of the major dietary sources of stilbenes but their concentration is relatively low as compared to other phenolic compounds (Pace-Asiak et al. 1995). Grape seeds contain low amounts of stilbenes (Pezet and Cuenat 1996), but a substantial amount of these compounds may be found in grape stems (Sun et al. 2003). However, grape stems contribute little to these compounds in wine due to their poor diffusion property (Sun et al. 2006).

Resveratrol (a monomeric stilbene) is the major stilbene of grapes. It is synthesized from phenylalanine and can exist in two isomeric forms. In wines, both isomeric forms were detected (Sun et al. 2003) due to photochemical isomerization of trans-form into $c i s$-form during wine making (Jeandet et al. 1995; Roggero and Garcia-Parrilla 1995).

Stilbenes can also occur in oligomeric and polymeric forms, known as viniferins. They are induced by oxidative polymerization of monomer resveratrol through the activity of a peroxidase (Jean-Denis et al. 2006). Many viniferins have been reported so far in grapes including $\varepsilon$-viniferin and $\delta$-viniferin, dimeric resveratrol (Pezet et al. 2003; Vitrac et al. 2005) and $\alpha$-viniferin, trimeric resveratrol (Pryce and Langcake 1977). Stilbenoids such as ampelopsin-A (dimeric resveratrol) and hopeaphenol (dimeric ampelopsin A) have also been identified (Jeandet et al. 2000; Guebaila et al. 2006).

The stilbene contents in wines varied considerably due to several factors like climate, grape variety, fungal infection (Perrone et al. 2007), UV light, metal ions (Pussa et al. 2006) and enological methods (Gambuti et al. 2004). It has been shown that red wine is usually more concentrated in stilbenes than rose and white wine as this depends on the skin contact of the must and the high phenolic content of grape cultivars during fermentation (Perrone et al. 2007). Many reports have been published targeted towards the quantification of stilbenes in different wines (Vitrac et al. 2005; Guebaila et al. 2006; Naugler et al. 2007).

\section{Importance of grape phenolics to human health}

The medicinal and nutritional value of grapes has been proclaimed for thousands of years. Several ancient Greek philosophers praised the healing power of grapes usually in the form of wine (Sun and Spranger 2005). Grape leaves have been used to stop bleeding, inflammation, pain, and diarrhea. Unripe grapes used to treat sore throats and dried grapes (raisins) to cure constipation and thirst. Round, ripe, and sweet grapes have been used to treat a range of health problems including cancer, cholera, smallpox, nausea, eye infections, skin, kidney, and liver 
diseases (Shi et al. 2003). Grape berries are prescribed as laxatives and as a diuretic in case of gastrointestinal and circulatory disturbances, or for the treatment of liver or kidney diseases (Stervbo et al. 2007). Grape phenolics have been proved to possess several health promoting properties playing an important role in the inhibition of carcinogenesis, mutagenesis, and cardiovascular diseases. These activities have been associated to their in vivo and in vitro antioxidative activities. Flavonoids in grape seeds have also been reported to exhibit activities against peptic ulcer (Saito et al. 1998) and several dermal disorders (Bomser et al. 1999).

\section{Antioxidant activity}

Phenolics including flavonoids and related polyphenols from wine and grape seeds have generated remarkable interest based on several reports (both in vivo and in vitro) of their antioxidant and free radical scavenging properties. A clinical report has shown that procyanidin oligomers from grape seeds are 20 and 50 times more potent antioxidant than vitamin $\mathrm{C}$ and E, respectively (Uchida 1980). Silva et al. (1991) found that monomeric and polymeric grape seed proanthocyanidins have superoxide and hydroxyl radicals scavenging activity. They also reported that certain polyphenols, for example, epicatechin-3-Ogallate, procyanidins $\mathrm{B} 2$ and $\mathrm{B} 2-3-\mathrm{O}$-gallate, had higher superoxide radical trapping activity at $\mathrm{pH} 9$ than at $\mathrm{pH}$ 7.5.

Kanner et al. (1994) found that red wine phenolics inhibit myoglobin, cytochrome $\mathrm{C}$ and iron ascorbate catalyzed lipid peroxidation. They also compared the antioxidative capacity of wine phenolics and $\alpha$-tocopherol and concluded that wine phenolics were twice more potent antioxidants than that of $\alpha$-tocopherol. It was shown that gallic acid, resveratrol, and tannic acid exerted same inhibition on lipid peroxidation which was greater than $\mathrm{D}-\mathrm{L}-\alpha$-tocopherol. Cuendet et al. (2000) proved that trans-piceide, a glucoside derivative of resveratrol, could effectively scavenge free radicals.

An in vivo study regarding the antioxidant effect showed that grape seed proanthocyanidins exhibited a superior protective effect than vitamin $\mathrm{E}$, vitamin $\mathrm{C}$, vitamin $\mathrm{E}$ plus $\mathrm{C}$ and $\beta$-carotene against lipid peroxidation and DNA fragmentation in mice (Bagchi et al. 1998). Resveratrol was also reported to inhibit platelet aggregation and LDL oxidation, protecting liver from lipid peroxidation in rats, apart from its anticarcinogenic activities (Teissedre et al. 1996). Another in vitro study showed that grape seed procyanidins might reduce the oxidation of polyunsaturated fatty acids in mouse liver microsomes (Bouhamidi et al. 1998). Tedesco et al. (2000) found antioxidant activity of nonalcoholic constituents of red wine.

\section{Anti-cardiovascular diseases activity}

Coronary heart disease (CHD), a serious health condition affecting a significant amount of the population of the developed countries, is usually associated to high cholesterol levels in blood. In particular, high levels of low density lipoproteins (LDL) in plasma may play a role in the initiation of atherosclerotic plaque. Grape, wine, and grape seed extracts inhibit the oxidation of LDL and platelet aggregation and preventing CHD have been shown by several in vitro and clinical studies (Frankel et al. 1993, 1995; Gryglewsk et al. 1987; Mangiapane et al. 1992). Polyphenols (mainly catechins and procyanidins) of grape seeds play a major role in the observed inhibition of LDL oxidation due to their antioxidant activity and platelet aggregation inhibition (Manthey et al. 2002).

The consumption of purple grape juice offered a good protection against the oxidation of LDL cholesterol, as shown by an in vivo study with dogs, monkeys, and humans, from which it could be inferred that the flavonoids of purple grape juice and red wine may inhibit the initiation of atherosclerosis (Folts 2002). Another study shows that moderate red wine consumption for 4 weeks is associated with desirable changes in high density lipoproteincholesterol (HDL-C) and fibrinogen compared with water with or without red grape extract (Hansen et al. 2005). The impact of wine on the measured cardiovascular risk factors thus seems primarily explained by an alcohol effect. A study done by Sato et al. (1999) showed that animals fed with grape seed phenolics (GSP) had a lower myocardial infarction rate due to scavenging of free radicals produced during ischemia and reperfusion. Sato et al. (2001) also showed that in rats, fed with $50-100 \mathrm{mg} / \mathrm{kg}$ of GSP, the number of apoptotic cells could be reduced along with the lessening in free radicals production. 
An in vitro study of Kaur et al. (2007) on peripheral blood mononuclear cells showed that resveratrol derivatives are 20 - to 10 -fold more efficient in inhibiting the tissue factor induction which is responsible for blood coagulation and thrombosis. The same group previously reported the same effect of these derivatives on the vascular (Pendurthi et al. 1999) and endothelial cells (Pendurthi and Rao 2002).

Some studies were also carried out to determine whether the alcohol in wine is responsible for the reduced levels of LDL in blood of moderate wine drinkers. Frankel et al. (1993) diluted red wine till $10 \mu \mathrm{mol} / \mathrm{l}$ total phenolics (1,000 times dilution) in order to evaluate in vitro effect of wine phenolics on human LDL oxidation inhibition. Diluted wine and quercetin at $10 \mu \mathrm{mol} / \mathrm{l}$ evenly repressed the human LDL oxidation, proving that this inhibition was from constituents other than alcohols. Interestingly, the inhibition was considerably higher than that induced by $\alpha$-tocopherol. Another study indicated that several red grape polyphenols inhibit cardiac voltage-gated sodium channel and that this effect may contribute to the documented cardioprotective efficacy of red grape products (Wallace et al. 2006).

\section{Anti-inflammation and anti-ulcer activity}

Apart from the other described activities, grape seed polyphenols (procyanidin) are also capable of inhibiting some enzymes which catalyze the release of many substances promoting inflammation, such as, histamine, serine protease, prostaglandin, and leukotrienes (Amella et al. 1985; Middleton and Drzewieki 1983; Pearce et al. 1984). Procyanidins was also proved to be able to inhibit the activation of hyaluronidase, a proteoglycan splitting enzyme that attacks various tissues during inflammation. This activity was associated to the antihistaminic effect and to their ability to strengthen cell membranes of basophils and mast cells, which contain the allergens, thus preventing the hypersensitivity to pollens and food allergens (Hansen 1995).

In rats, grape seed extracts containing high or low flavonol contents showed anti-ulcer activity (Saito et al. 1998). This protective effect was higher in high flavonol containing extracts than in those with a low content. The authors also found that catechin, procyanidin B3 and dimeric and trimeric procyanidins did not show any defensive activity against ulcer while tetramers, pentamers, and hexamers of these were active. The authors postulated that the activity shown by longer oligomeric procyanidins might be due to their ability to bind to the proteins present on the stomach surface.

\section{Anticancer and antimutagenic activities}

A variety of procyanidins from grapes and their seeds have been shown to prevent the growth of cancer cells. The anti-mutagenic activity of procyanidins from $V$. vinifera on Saccharomyces cerevisiae was examined by Liviero and Puglisi (1994). They found that procyanidins from grapes at $0.5 \mathrm{mg} / \mathrm{ml}$ induced a $65 \%$ decrease of the mitochondrial spontaneous mutability in Saccharomyces strain S288C. At the same concentration of procyanidins from grapes, $92 \%$ reduction rate was observed in the mutation rate for the nuclear genetic determinant canavanine sensitivity. Another report (Tyagi et al. 2003) also shows that grape seed extract has a possible role in antiproliferation and apoptosis of human prostate carcinoma.

Nakagawa et al. (2001) reported the effect of resveratrol on the inhibition of the growth of breast cancer cells. Suppression in the growth of these cells by resveratrol was reported to occur through apoptosis. Another anti-carcinogenic study showed that resveratrol was capable to inhibit tumor initiation, promotion and progression and also explaining how it intervened in each stage (Jang et al. 1997). At first stage, resveratrol acted as an antioxidant and drug metabolizing enzymes of phase II were induced. At the second step, it mediated anti-inflammatory effects and the enzymes like cyclooxygenase and hydroperoxidase were inhibited. Finally human leukemia cell differentiation was induced by resveratrol (antiprogression activity) along with the inhibition of the development of preneoplastic lesions in carcinogen treated mouse mammary glands.

Bomser et al. (2000) noted that ornithine decarboxylase (ODC), a rate-limiting enzyme in polyamine biosynthesis could have an essential role in diverse biological processes including cell proliferation and differentiation. High levels of ODC are associated with increased risk for cancer. Grape seed polyphenols extract containing mainly oligomeric and polymeric proanthocyanidins was shown to inhibit epidermal ODC activity in mice. Previously, 
Bomser et al. (1999) had found that grape seed extract containing mainly oligomeric and polymeric proanthocyanidins showed anti-tumor activity in mouse skin epidermis. A methylated derivative of resveratrol is also reported for the human colon cancer cell lines inhibition, about 100-fold more active than resveratrol (Schneider et al. 2003).

The p53 gene suppresses tumor formation and induces apoptosis. Modulation of p53 expression by red wine and its polyphenolic contents was studied on three human breast cancer cell lines and one colon cancer line by Soleas et al. (2001), which showed that these polyphenols, including quercetin, catechin, trans-resveratrol and caffeic acid did not affect p53 gene expression in two of the breast cancer lines. Resveratrol, on the other hand, did decrease the expression of this gene in breast cancer cells of a wild type (MCF-7), while catechin and caffeic acid increased its expression but in a concentration independent manner. Caffeic acid and resveratrol reduced the expression of p53 in colon cancer cell lines, but this reduction again was not dose-responsive. Soleas et al. (2001) concluded that anticarcinogenic properties of wine should not be attributed to the modulation of p53 gene expression by these wine polyphenolic constituents. An in vitro study showed that methylated derivative of resveratrol induces apoptosis in human lymphoblastoid cell independently of their p53 status (Schneider et al. 2004).

Basly et al. (2000) studied the estrogenic/antiestrogenic effects of resveratrol isomers on the in vitro human breast cancer cells, finding that the cis form was less effective than trans in both cell lines. The 2,2-diphenyl-1-picrylhydrazyl (DPPH) and $\mathrm{FeCl}_{3}$ reduction assays showed that these isomers could be both antioxidant and prooxidant, depending on their concentrations.

\section{Other biological activities}

The effect of plant flavonoids on intestinal microflora has also been investigated. Tebib et al. (1996) reported that monomeric proanthocyanidins of grape seeds did not affect the activities of fecal bacterial enzymes of rats. However, polymeric proanthocyanidins showed 'a beneficial colonic protective effect' by reducing colonic enzymatic activity of $\beta$-glucosidase, $\beta$-glucuronidase, mucinase and nitroreductase due to a dilution effect.
Polymeric tannin supplementation was shown to stimulate fermentative activities without increasing the activity of harmful enzymes on animal models. Chung et al. (1998) reported that tannic acid inhibited the growth of intestinal bacteria such as Clostridium perfringens, Enterobacter cloacae, Escherichia coli and Salmonella typhimurium while showing no inhibitory effect on $B$. infantis or lactic acid bacteria Lactobacillus acidophilus.

A fluorescence assay was developed to determine the bacterial degradation of flavonoids by Schoefer et al. (2001). This assay was proved to be able to distinguish the ability of colonic bacteria to degrade various flavonoids with the exception of catechin which could not be determined due to the lack of the quenching effect of the fluorescing compound. Future studies may reveal details on the mechanisms of flavonoid degradation by colonic microflora.

Khanna et al. (2001) showed that grape seed proanthocyanidin extract containing $5 \mathrm{mg} / \mathrm{g}$ trans-resveratrol induced the expression of vascular endothelial growth factor (VEGF) in keratinocytes. Therefore, GSP extract containing resveratrol can be used to treat dermal wounds and other dermal disorders.

Polyphenols in grape seed extract have been shown to reduce food intake in animal models. A study on humans showed that grape seed reduced energy intake without further effects on satiety, mood or tolerance (Vogels et al. 2004). Flechtner-Mors et al. (2004) also showed that moderate consumption of white wine is effective in weight loss in overweight and obese subjects.

\section{Major grape diseases}

As a crop, grapes are susceptible to many diseases. Downy mildew, powdery mildew, grey mold, anthracnose, black rot, and crown gall are the major grape diseases around the world. All of these-with the exception of crown gall, are caused by fungi that attack the berries, reducing yield and quality. Crown gall is caused by a bacterium and can kill the plant. The degree of susceptibility varies depending on the variety, but damage can be harsh if no pest management is carried out.

The most threatening diseases to the grapevines are powdery and downy mildew caused by two 
different fungi, Uncinula necator and Plasmopara viticola, respectively. Downy mildew, caused by $P$. viticola (oomycete fungi), is the disease which affects both leaves and fruit (Madden et al. 2000). Powdery mildew is another widespread and destructive disease of grapevines worldwide. The damage caused by the pathogen, U. necator, has been noticed from the studies of the disease on cultivars of the European grape species (David et al. 2001).

Botrytis cinerea, the causal agent of grey mould or botrytis bunch rot in grapes, is responsible for considerable economic damage in vineyards worldwide. During the last 50 years, management of $B$. cinerea has relied heavily upon the use of synthetic chemicals (Rosslenbroich and Stuebler 2000). Grapevines are also attacked by viruses such as the nepovirus, grapevine fan leaf virus (GFLV). GFLV is responsible for an important and widespread degeneration of grapevine, causing a substantial loss in grape yield (up to $80 \%$ ), low fruit quality, and a progressive decline of infected vines that can eventually lead to plant mortality (Martelli 1993; Martelli and Savino 1990).

Pest and disease control

In nearly all parts of the world, pest and disease control in grapevines is generally achieved by widespread application of fungicides and pesticides, which results in high costs and a negative environmental impact. Scientists have been working hard to obtain grapevine varieties with an increased resistance against pathogens (Peixe et al. 2004). A great effort has been made to obtain improved grapevines through controlled cross-breeding between American and Asian cultivars and the resulting plants have been selected and their resistance evaluated (This et al. 2006). While this method presents unquestionable advantages, it is a slow process which also contributes in the reduction of genetic variability and loss of important quality of wine. Therefore, the use of biotechnological methods for this purpose is gaining much attention now.

\section{Resistance in grapes}

Plants like other organisms have developed different mechanisms to respond to different stresses such as unfavorable environmental conditions, nutrition deficiency and pathogen attack (Downie et al. 2004; Matsumoto et al. 2004). Plant defense system (resistance) against pathogens comprises a number of mechanisms, the most significant of which is the biosynthesis of secondary metabolites. A certain group of compounds have been found to be involved or associated with plant defense mechanisms. These compounds, known as phytoalexins, are low molecular weight, antimicrobial secondary metabolites (Harborne 1999; Kuc 1995; Purkayashta 1995).

In grapevine, the most frequently observed and best characterized defense reactions to fungal infection are the accumulation of phytoalexins as well as pathogen related (PR) proteins (Derckel et al. 1999). Figure 4 shows some of the phytoalexins isolated from grapevine. Phytoalexins from the Vitaceae in general, have been the subject of numerous studies during the past decade as these compounds are thought to have implications in both phytopathology and human health.

Upon infection, grapevines rely upon preformed and inducible resistance mechanisms for defense (Gabler et al. 2003; Keller et al. 2003). The cuticle layer and cell wall physically resist the penetration of hyphae while tannins and phenolics inhibit fungal enzymes involved in pathogenesis (Goetz et al. 1999; Sarig et al. 1998). Early inducible responses include the deposition of new cell wall material, the release of reactive oxygen species (ROS) and hypersensitive cell death (HR) at the infection site (Hammerschmidt and Smith-Becker 1999). It has been demonstrated that various biotic and abiotic agents can activate defense mechanism in grape berries and leaves enhancing the resistance against diseases (Table 1).

\section{Phytoalexins from grapes}

Stilbenes are generally biologically active compounds that also have antifungal activities against various pathogens such as Cladosporium cuccumerinum, Pyricularia oryzae (Langcake and Pryce 1976), Plasmopara viticola (Dercks and Creasy 1989; Langcake 1981), and Sphaeropsis sapinea (Celimene et al. 2001).

Resveratrol is the major phytoalexin produced in grapevines along with its derivatives such as piceide, pterostilbene and $\varepsilon^{-}, \alpha-, \beta$-, and $\delta$-viniferin (Jeandet et al. 2002; Pezet et al. 2004). Resveratrol was found to accumulate in the abaxial surface of leaves and in 
Fig. 4 Chemical structures of stilbene phytoalexins. Glc: glucosyl $\left(\mathrm{C}_{6} \mathrm{H}_{11} \mathrm{O}_{5}\right)$<smiles>COc1cc(O)cc(/C=C/c2ccc(O)cc2)c1</smiles><smiles>Oc1ccc(/C=C\c2cc(O)cc(OC(Cl)(Cl)Cl)c2)cc1</smiles><smiles>CCOc1ccc(/C=C/c2cc(O)cc(O)c2)cc1</smiles><smiles>CC(C)CC=Cc1cc(O)cc(OC(C)C)c1</smiles><smiles>CCOC(=O)c1cc(OC)cc([N+](=O)[O-])c1</smiles><smiles>COc1ccc(/C=C\c2cc(O)cc(O)c2)cc1</smiles><smiles>Oc1cc(O)cc(/C=C\c2ccc(O)c(O)c2)c1</smiles><smiles>Oc1ccc(/C=C/c2cc(O)cc(O)c2)cc1</smiles>

skin of berries in the range of $40-400 \mu \mathrm{g} / \mathrm{g}$ fresh weight (Adrian et al. 2000; Jeandet et al. 1991). A study on grape plantlets proved the existence of a positive correlation between resveratrol synthesis in leaves (induced by UV) and field resistance (Sbaghi et al. 1995). Regarding fungal infection resistance, an in vitro study showed that at the concentration of $90 \mu \mathrm{g} / \mathrm{ml}$, resveratrol was able to inhibit conidial germination by $50 \%$ while reduction in mycelial growth was observed in the range of $60-140 \mu \mathrm{g} / \mathrm{ml}$ (Adrian et al. 1997).<smiles>Oc1ccc(/C=C/c2cc(O)cc3c2C(c2cc(O)cc(O)c2)C(c2ccc(O)cc2)O3)cc1</smiles>

Pterostilbene is the dimethylated derivative of resveratrol. A study showed that it is fivefold more toxic than resveratrol, completely inhibiting conidial germination at concentrations ranging from 52 to $60 \mu \mathrm{g} / \mathrm{ml}\left(\mathrm{ED}_{50}\right)$ and 18 to $20 \mu \mathrm{g} / \mathrm{ml}$ (Adrian et al. 1997; Langcake 1981; Pezet and Pont 1990). The methylation of the hydroxyphenyl groups in phenolics could potentially resulted in an enhanced biocidal activity as these two different stilbenes indicated (Pezet and Pont 1990). The oxidative dimers of resveratrol have formed a new class of compounds 
Table 1 Examples of inducing agents with demonstrated cellular and biological activity on grape tissues (partially adapted from Elmer and Reglinski 2006)

\begin{tabular}{|c|c|c|}
\hline Inducing agent & Reported activity & References \\
\hline Methyl jasmonate & $\begin{array}{l}\text { Accretion of phytoalexins and defense-related } \\
\text { proteins along with the induction of the oxidative } \\
\text { burst }\end{array}$ & $\begin{array}{l}\text { Repka et al. (2004), Belhadj } \\
\text { et al. (2006), Vezzulli et al. } \\
(2007)\end{array}$ \\
\hline Aluminium chloride & Accumulation of phytoalexins in grapevine leaves & $\begin{array}{l}\text { Adrian et al. (1996), Borie } \\
\text { et al. (2004) }\end{array}$ \\
\hline $\begin{array}{l}\text { Laminarin }(\beta-1,3 \text {-glucan from } \\
\text { Laminaria digitata })\end{array}$ & $\begin{array}{l}\text { Induction of defense-related genes and oxidative } \\
\text { burst. Enhancement is resistance against } B \text {. cinerea } \\
\text { was also observed }\end{array}$ & Aziz et al. (2003) \\
\hline $\begin{array}{l}\text { Benzo }(1,2,3) \text { thiadiazole-7- } \\
\text { carbothioic acid } S \text {-methyl ester }\end{array}$ & $\begin{array}{l}\text { High levels of resveratrol and anthocyanins with the } \\
\text { induced resistance against } B \text {. cinerea with the } \\
\text { accumulation of chitinase class III transcript }\end{array}$ & $\begin{array}{l}\text { Owen et al. (2002), Iriti et al. } \\
\text { (2004) }\end{array}$ \\
\hline Oligogalacturonide & $\begin{array}{l}\mathrm{H}_{2} \mathrm{O}_{2} \text { production, induction of defense-related genes } \\
\text { in cell suspensions, and elevation of resistance to } \\
\text { B. cinerea in detached leaves }\end{array}$ & $\begin{array}{l}\text { Poinssot et al. (2003), Aziz } \\
\text { et al. (2004) }\end{array}$ \\
\hline Chitosan & $\begin{array}{l}\text { Phenylalanine ammonia-lyase activity induction and } \\
\text { elevation of resistance to } B \text {. cinerea }\end{array}$ & $\begin{array}{l}\text { Romanazzi et al. (2002), } \\
\text { Patricia et al. (2006) }\end{array}$ \\
\hline 5-Chlorosalicylic acid & $\begin{array}{l}\text { Enhanced production of phenolics, and field efficacy } \\
\text { against } B \text {. cinerea }\end{array}$ & $\begin{array}{l}\text { Duxbury et al. (2004), } \\
\text { Reglinski et al. (2005) }\end{array}$ \\
\hline Chitogel & Reduced $B$. cinerea infection on plantlet leaves & Ait-Barka et al. (2004) \\
\hline
\end{tabular}

known as viniferins. A study by Pezet et al. (2004) showed that $\delta$-viniferin exhibited toxicity similar to that of pterostilbene against $P$. viticola.

The above reports constitute clear evidence of the substantial antifungal activity of stilbenes, which in turn suggests their participation in the resistance against fungal grapevine diseases, thus supporting their proposal as indicators of resistance. Pool et al. (1981) studied the relationship between phytoalexins production potential and resistance to diseases in grapevine, concluding that there was a positive correlation in both the speed and the intensity of resveratrol synthesis and the resistance of grapevine varieties to fungal diseases caused by $B$. cinerea or $P$. viticola. Unfortunately, the production of resveratrol in field-growing grapevines has proved to be very sensitive to a wide range of environmental factors, thus limiting its use as a marker for disease resistance (Barlass et al. 1987).

Pathogenesis-related proteins from grapes

Pathogenesis-related proteins are typically acidic, of low molecular mass and highly resistant to proteolytic degradation. They accumulate in berries and leaves of grapevines (Fig. 5) in response to pathogen attack and are thought to contribute in resistance (Giannakis et al. 1998). The type of tissue, developmental stage and type of infecting pathogen were observed to vary the pattern of PR-protein expression (Busam et al. 1997; Derckel et al. 1999; Robert et al. 2002). In grape berries, PR-protein levels are also produced constitutively as a normal part of the ripening process (Robinson et al. 1997; Tattersall et al. 1997) and this has been a prophylactic measure against environmental stress and pathogen attack (Davies and Robinson 2000). Chitinase and thaumatin-like proteins represent the predominant PR-proteins in grape berries. These two protein families account for half of the soluble protein in ripe grapes (Waters et al. 1998). Bezier et al. (2002) showed that grapevine leaves and berries expressed polygalacturonase inhibitor proteins (PGIPs) in response to infection by $B$. cinerea. PGIPs are thought to contribute to disease resistance by inhibiting the degradation of the plant cell wall by fungal polygalacturonases.

Pathogenesis-related proteins can also be induced in leaves and berries as part of a defensive response to the classical PR protein gene-inducers (wounding, chemical elicitors, pathogen attack, or abiotic stress) by the expression of specific PR genes (Jacobs et al. 
Fig. 5 Pathogen related $(P R)$ proteins in grapevine. 1-Busam et al. (1997), 2Ferreira et al. (2001), 3Hayasaki et al. (2001), 4Vivier and Pretorius (2002), 5-Colova-Tsolova (2000), 6-Renault et al. (1996), 7-Kraeva et al. (1998)

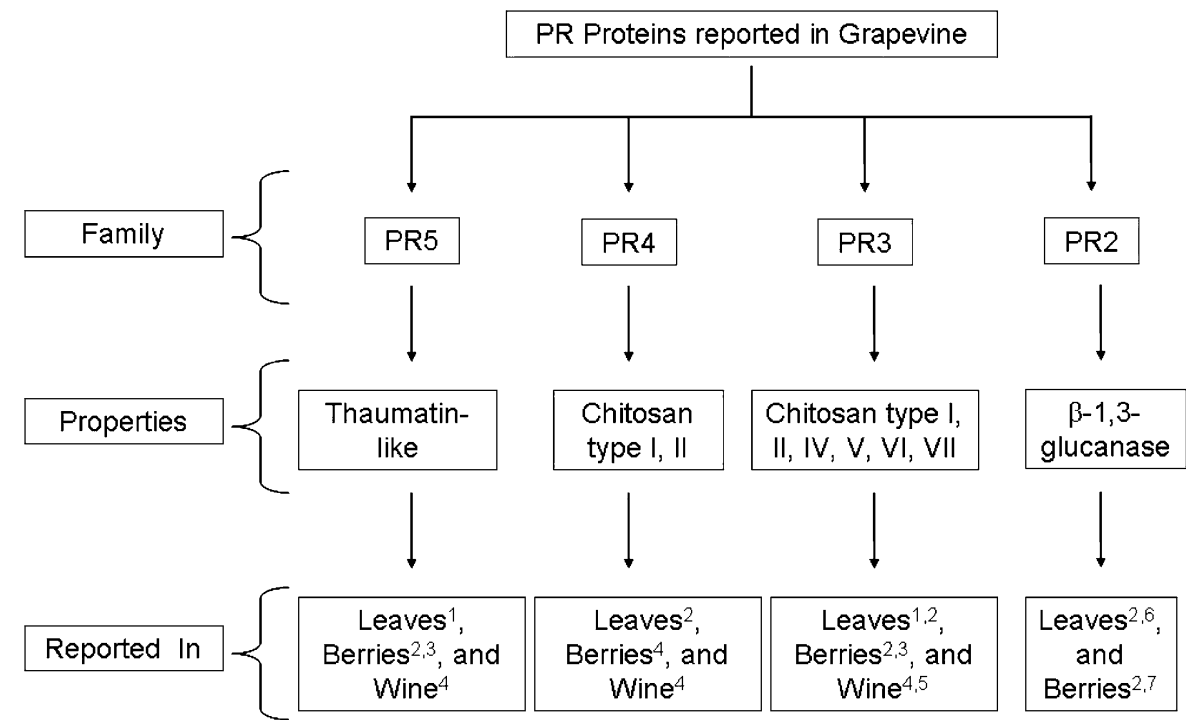

1999; Robinson and Davies 2000). These processes modulate the levels and proportions of the PR proteins in grapes, apparently depending on the factors like cultivar, region, climate, and agricultural practices (Monteiro et al. 2003).

\section{Biotechnology of grapevine}

Grapevine biotechnology is one of the most promising developments but on the other hand increasingly faced with many contradictions. As with plant biotechnology in general, several technical factors dictate the speed of the current progress in this field. These factors include the easiness with which the relevant plant species can be operated in tissue culture, be transformed with foreign DNA and be regenerated into new plantlets.

Vitis vinifera, being a woody perennial, initially proved to be reluctant to these manipulations. Very few of the early attempts, to transform grapevine, were successful. Now, several groups have produced transgenic grapevines that are presently at varying stages of evaluation. Still there is no universal protocol to transform or genetically engineer all grapevine cultivars. Significant progress has been made, however, for the establishment of this technology over the world and the success rate should increase with the coming years (Kikkert et al. 2001).
Genetic engineering is commended as an amazing achievement and in the grapevine industries. This technology and its supporting disciplines lead to the establishment of stress tolerant and disease resistant varieties of Vitis vinifera, with increased productivity, efficiency, sustainability and environmental friendliness, especially regarding improved pest and disease control, water use efficiency and grape quality. The implementation and successful commercialization of genetically improved grapevine varieties will only materialize if an array of hurdles posed by scientific, legal and regulatory issues, intellectual property and patenting (Kikkert et al. 2001), political, economic, and not least, the negative public perception of genetically modified products (Pretorius 2000) can be solved. Grapevine biotechnology, currently practiced in all major viticultural research centers worldwide, is focused on several issues (Table 2).

\section{Conclusion and perspectives}

Economically, grapevine is one of the most important crop in the world and has a deeply rooted significance in human culture. The functional ingredients of grapevine include several flavonoids which have been reported to exhibit different activities including antioxidant, anti-cancer, and prevention of cardiovascular disease and the treatment of several skin disorders. Resistance of plants to infection by 
Table 2 Targets for the genetic improvement of grapevine cultivars

\begin{tabular}{|c|c|c|c|}
\hline $\begin{array}{l}\text { Desirable } \\
\text { properties }\end{array}$ & Examples of current potential target genes & Focus area & References \\
\hline $\begin{array}{l}\text { Pathogen } \\
\text { tolerance }\end{array}$ & $\begin{array}{l}\text { Virus coat proteins, glucanase- and } \\
\text { chitinase-encoding genes, anti-microbial } \\
\text { peptides }\end{array}$ & $\begin{array}{l}\text { Pathogen-derived resistance strategies, } \\
\text { defence and defence signaling against } \\
\text { fungal and bacterial pathogens }\end{array}$ & $\begin{array}{l}\text { Yamamoto et al. (2000), } \\
\text { Vidal et al. (2006), } \\
\text { Mauro et al. (1995) }\end{array}$ \\
\hline $\begin{array}{l}\text { Resistance to } \\
\text { abiotic } \\
\text { stress }\end{array}$ & $\begin{array}{l}\text { Tonoplast integral proteins, carotenoid } \\
\text { biosynthetic genes, antifreez genes }\end{array}$ & $\begin{array}{l}\text { Carotenoid biosynthesis and control, } \\
\text { polyamines and their role in stress, } \\
\text { aquaporins }\end{array}$ & Tsvetkov et al. (2000) \\
\hline $\begin{array}{l}\text { Improvement } \\
\text { in quality } \\
\text { factors }\end{array}$ & $\begin{array}{l}\text { UDP-glucose:flavanoid 3-O- } \\
\text { glucosyltransferase, Silencing of } \\
\text { polyphenol oxidase, sucrose } \\
\text { transporters, baranase gene }\end{array}$ & $\begin{array}{l}\text { Phloem loading and unloading, isolation of } \\
\text { seed-specific promoters, anthocyanin } \\
\text { biosynthesis and control, oxidation } \\
\text { reactions }\end{array}$ & $\begin{array}{l}\text { Fillion et al. (1999), } \\
\text { Kobayashi et al. (2001, } \\
\text { 2002), Boss et al. } \\
\text { (1996) }\end{array}$ \\
\hline
\end{tabular}

phytopathogenic microorganisms is the result of multiple defense reactions comprising both constitutive and inducible barriers. In grapevine, the best characterized defense mechanisms are the accumulation of phytoalexins and the synthesis of PR-proteins. Particular attention has been given to stilbene phytoalexins (e.g. resveratrol) produced by Vitaceae. Despite the enormous amount of research carried out on grapevine phytochemistry, there is still a lot to be done in this field. The current advances achieved in analytical platforms and methodologies can and in fact will, really facilitate the isolation of new phytochemicals from grapevine with higher medicinal potential or novel bioactivities. The identification and characterization of different disease-resistant grapevine cultivars, at the gene, protein or metabolite level, is also a focal point of the grapevine research today. By the integration of different 'omics' technologies, it will be possible to better understand the total network of plant responses to various external factors including pathogen attack. In this way, a systems biology approach will be developed to explore and exploit the possible synergism between genes, proteins and metabolites.

Acknowledgments The authors would like to acknowledge The Higher Education Commission (HEC) of Pakistan for the support of Kashif Ali. This work was supported by ERAPG under the project Genomic Research-Assisted breeding for Sustainable Production of Quality GRAPEs and WINE (http://urgi.versailles.inra.fr/projects/GRASP/).

Open Access This article is distributed under the terms of the Creative Commons Attribution Noncommercial License which permits any noncommercial use, distribution, and reproduction in any medium, provided the original author(s) and source are credited.

\section{References}

Adrian M, Jeandet P, Bessis R, Joubert JM (1996) Induction of phytoalexin (resveratrol) synthesis in grapevine leaves treated with aluminum chloride $\left(\mathrm{AlCl}_{3}\right)$. J Agric Food Chem 44:1979-1981

Adrian M, Jeandet P, Veneau J, Weston LA, Bessis R (1997) Biological activity of resveratrol, a stilbenic compound from grapevines, against Botrytis cinerea, the causal agent for gray mold. J Chem Ecol 23:1689-1702

Adrian M, Jeandet P, Breuil AC, Levite D, Debord S, Bessis R (2000) Assay of resveratrol and derivative stilbenes in wines by direct injection high performance liquid chromatography. Am J Enol Vitic 51:37-41

Ait-Barka E, Eullaffroy P, Clement C, Vernet G (2004) Chitosan improves development, and protects Vitis vinifera L. against Botrytis cinerea. Plant Cell Rep 22:608-614

Alcalde-Eon C, Escribano-Bailon MT, Santos-Buelga C, Rivas Gonzalo JC (2006) Changes in the detailed pigment composition of red wine maturity and ageing-a comprehensive study. Anal Chem Acta 563:238-254

Amella AL, Bronner C, Briancon F, Haag M, Anton R, Landry Y (1985) Inhibition of mast cell histamine release by flavonoids and bioflavonoids. Planta Med 51:16-21

Asenstorfer RE, Markides AJ, Iland PG, Jones GP (2003) Formation of vitisin A during red wine vinification and maturation. Aust J Grape Wine Res 9:40-46

Aziz A, Pionssot B, Daire X, Adrian M, Bezier A, Lambert B, Joubert JM, Pugin A (2003) Laminarin elicits defense responses in grapevine and induces protection against Botrytis cinerea and Plasmopara viticola. Mol Plant Microbe Interact 16:1118-1128

Aziz A, Heyraud A, Lambert B (2004) Oligogalacturonide signal transduction, induction of defense-related responses and protection of grapevine against Botrytis cinerea. Planta 218:767-774

Baderschneider B, Winterhalter P (2001) Isolation and characterization of noval benzoates, cinnamates, flavonoids, and lignans from Riesling wine and screening for antioxidant activity. J Agric Food Chem 49:2788-2798

Bagchi D, Garg A, Krohn R, Bagchi M, Bagchi DJ, Balmoori J, Stohs SJ (1998) Protective effects of grape seed proanthocyanidins and selected antioxidant against TPA- 
induced hepatic and brain lipid peroxidation and DNA fragmentation, and peritoneal macrophage activation in mice. Gen Pharmacol 30:771-776

Barlass M, Miller RM, Douglas TJ (1987) Development of methods for screening grapevines for resistance to downy mildew. II. Resveratrol production. Am J Enol Vitic 38:65-68

Basly JP, Marre-Fournier F, Le-Bail JC, Habrioux G, Chulia AJ (2000) Estrogenic/antiestrogenic and scavenging activities of trans- and cis-resveratrol. Life Sci 66:769-777

Bavaresco L, Cante E, Fregoni M, Trevisan M (1997) Constitutive stilbene contents of grapevine cluster stems as potential source of resveratrol in wine. Vitis 36:115-118

Belhadj A, Saigne C, Telef N, Cluzet S, Bouscaut J, CorioCostet MF, Mearillon JM (2006) Methyl jasmonate induces defense responses in grapevine and triggers protection against Erysiphe necator. J Agric Food Chem 54:9119-9125

Bertrand M (2008) Virgin grape seed oil: is it really a nutritional highlight? Eur J Lipid Sci Technol 110:645-650

Bezier A, Lambert B, Baillieul F (2002) Study of defenserelated gene expression in grapevines leaves and berries infected with Botrytis cinerea. Eur J Plant Pathol 108: $111-120$

Bisson LF (1999) Stuck and sluggish fermentation. Am J Enol Vitic 50:107-119

Blateyron L, Sablayrolles JM (2001) Stuck and slow fermentations in enology: statistical study of causes and effectiveness of combined additions of oxygen and diammonium phosphate. J Biosci Bioeng 91:184-189

Boido E, Alcalde-Econ C, Carrau F, Dellacassa E, RivasGonzalo JC (2006) Ageing effect on pigment composition and color of Vitis vinifera L. cv. Tannat wines. Contribution to the main pigment families to wine color. J Agric Food Chem 54:6692-6704

Bomser J, Singletary K, Wallig MA, Smith MAL (1999) Inhibition of TPA-induced tumor promotion in CD-1 mouse epidermis by a polyphenolic fraction from grape seeds. Cancer Lett 135:151-157

Bomser J, Singletary K, Meline B (2000) Inhibition of 12-Otetradecanoylphorbol-13-acetate (TPA)-induced mouse skin ornithine decarboxylase and protein kinase $\mathrm{C}$ by polyphenolics from grapes. Chem Biol Interact 127:45-59

Borie B, Jeandet P, Parize A, Bessis R, Adrian M (2004) Resveratrol and stilbene synthase mRNA production in grapevine leaves treated with biotic and abiotic phytoalexin elicitors. Am J Enol Vitic 55:60-64

Boselli E, Boulton RB, Thorngate JH, Frega NG (2004) Chemical and sensory characterization of DOC red wines from Marxhe (Italy) related to vintage and grape cultivars. J Agric Food Chem 52:3843-3854

Boss PK, Davies C, Robinson SP (1996) Expression of anthocyanin biosynthesis pathway genes in red and white grapes. Plant Mol Biol 32:565-569

Bouhamidi R, Prevost V, Nouvelot A (1998) High protection by grape seed proanthocyanidins (GSPC) of polyunsaturated fatty acids against UV-C induced peroxidation. Comptes Rendus de 1 Academie des Sciences. Serie III 321:31-38

Bowers J, Boursiquot JM, This P, Chu K, Johansson H, Meredith C (1999) Historical genetics: the parentage of Chardonnay, Gamay, and other wine grapes of northeastern France. Science 285:1562-1565
Brun S, Cabanis JC, Mestres JP (1986) Analytical chemistry. Experientia 42:893-904

Busam G, Junghanns KT, Kneusel RE, Kassemeyer HH, Matern U (1997) Characterization and expression of caffeoylcoenzyme A 3-O-methyltransferase proposed for the induced resistance response of Vitis vinifera L. Plant Physiol 115:1039-1048

Castellari M, Versari A, Spinabelli U, Galassi S, Amati A (2000) An improved HPLC method for the analysis of organic acids, carbohydrates and alcohols in grape musts and wines. J Liq Chromatogr Relat Technol 23:2047-2056

Celimene CC, Smith DR, Young RA, Stanosz GR (2001) In Vitro inhibition of Sphaeropsis sapinea by natural stilbenes. Phytochemistry 56:161-165

Chen ECH (1978) The relative contribution of Ehrlich and biosynthetic pathways to the formation of fusel alcohols. J Am Soc Brew Chem 36:39-43

Cheynier VF, Trousdale EK, Singleton VL, Salgues MJ, Wylde $\mathrm{R}$ (1986) Characterization of 2-S-glutathionylcaftaric acid and its hydrolysis in relation to grape wines. J Agric Food Chem 34:217-221

Chung KT, Lu Z, Chou MW (1998) Mechanism of inhibition of tannic acid and related compounds on the growth of intestinal bacteria. Food Chem Toxicol 36:1053-1060

Colova-Tsolova V (2000) A highly efficient Agrobacterium transformation system in grape embryogenic cell suspension enable co-transformation using simultaneously two Agrobacteria carrying different selectable markers. Hortic Sci 35:393-394

Cooper HJ, Marshall AG (2001) Electrospray ionization Fourier transformation mass spectrometric analysis of wine. J Agric Food Chem 49:5710-5718

Creasy LL, Coffee M (1988) Phytoalexin production potential of grape berries. J Am Soc Hortic Sci 113:230-234

Crippen DD Jr, Morrison JC (1986) The effects of sun exposure on the phenolic content of Cabernet Sauvignon berries during development. Am J Enol Vitic 37:243-247

Cuendet M, Potterat O, Salvi A, Testa B, Hostettmann K (2000) A stilbene and dihydrochalcones with radical scavenging activities from Loiseleuria procumbens. Phytochemistry 54:871-874

David MG, Robert CS, Roger CP, Wayne FW, Richard MD (2001) Effects of powdery mildew on vine growth, yield, and quality of concord grapes. Plant Dis 85:137-140

Davies C, Robinson SP (2000) Differential screening indicates a dramatic change in mRNA profiles during grape berry ripening. Cloning and characterization of cDNAs encoding putative cell wall and stress response proteins. Plant Physiol 122:803-812

De Pascual-Teresea S, Rivas-Gonzalo JC, Santos-Buelga C (2000) Prodelphinidins and related flavanols in wine. Int J Food Sci Tech 35:33-40

Derckel JP, Baillieul F, Manteau S, Audran JC, Haye B, Lambert B, Legendre L (1999) Differential induction of grapevine defenses by two strains of Botrytis cinerea. Phytopathology 89:197-203

Dercks W, Creasy LL (1989) The significance of stilbene phytoalexins in the Plasmopara Viticola grapevine interaction. Physiol Mol Plant Pathol 34:189-202

Dixon RA (2001) Natural products and plant disease resistance. Nature 411:843-847 
Downey M, Harvey J, Robinson S (2003) Synthesis of flavonols and expression of flavonol synthase genes in the developing grape berries of Shiraz and Chardonnay (Vitis vinifera L.). Aust J Grape Wine Res 9:110-121

Downie A, Miyazaki S, Bonnert H, John P, Coleman J, Parry M, Haslam R (2004) Expression profiling of the response of Arabidopsis thaliana to methanol stimulation. Phytochemistry 65:2305-2316

Duxbury M, Hotter G, Reglinski T, Sharpe N (2004) Effect of chitosan and 5-chlorosalicylic acid on total phenolic content of grapes and wine. Am J Enol Vitic 55:191-194

Elmer PAG, Reglinski T (2006) Biosuppression of Botrytis cinerea in grapes. Plant Pathol 55:155-177

Escudero A, Hernandez-Orte P, Cacho J, Ferreira V (2000) Clues about the role of methional as character impact odorant of some oxidized wines. J Agric Food Chem 48:4268-4272

Ferreira RB, Piçarra-Pereira MA, Monteiro S, Loureiro VB, Teixeira AR (2001) The wine proteins. Trends Food Sci Tech 12:230-239

Fillion L, Ageorges A, Picaud S, Coutos-Thevenot PL, Romieu C, Delrot S (1999) Cloning and expression of a hexose transporter gene expressed during the ripening of grape berry. Plant Physiol 120:1083-1094

Flechtner-Mors M, Beisalski HK, Jenkinson CP, Adler G, Ditschuneit HH (2004) Effects of moderate consumption of white wine on weight loss in overweight and obese subjects. Int J Obes 28:1420-1426

Folts JD (2002) Potential health benefits from the flavonoids in grape products on vascular disease. Adv Exp Med Biol 505:95-111

Fournand D, Vicens A, Sidhoum L, Souquet JM, Moutounet M, Cheynier V (2006) Accumulation and extractability of grape skin tannins and anthocyanins at different advanced physiological stages. J Agric Food Chem 54:7331-7338

Fraile P, Garrido J, Ancin C (2000) Influence of a Saccharomyces cerevisiae selected strain in the volatile composition of rose wines. Evolution during fermentation. J Agric Food Chem 48:1789-1798

Frankel EN, Kanner J, German JB, Parks E, Kinsella JE (1993) Inhibition of oxidation of human low-density lipoprotein by phenolic substances in red wine. Lancet 341:454-457

Frankel WN, Waterhouse AL, Teissedre PL (1995) Principal phenolic phytochemicals in selected California wines and their antioxidant activity in inhibiting oxidation of human low-density lipoproteins. J Agric Food Chem 43:890-894

Fulcrand H, Remy S, Souquet JM, Cheynier V, Moutounet M (1999) Study of wine tannins oligomers by on-line chromatography electrospray ionization mass spectrometry. J Agric Food Chem 47:1023-1028

Gabler FM, Smilanick JL, Mansour M, Ramming DW, Mackey BE (2003) Correlations of morphological, anatomical, and chemical features of grape berries with resistance to Botrytis cinerea. Phytopathology 93:1263-1273

Gambuti A, Strollo D, Ugliano M, Lecce L, Moio L (2004) trans-Resveratrol, quercitin, (+)-catechin, and (-)-epicatechin content in south italian monovarietal wines: Relationship with maceration time and marc pressing during winemaking. J Agric Food Chem 52:5747-5751

Gardini F, Zaccarelli A, Belleti N, Faustini F, Cavazza A, Maruscelli M, Mastrocola D, Suzzi G (2005) Factors influencing biogenic amine production by a strain of $O e$ nococcus oeni in a model system. Food Control 16:609-618

Giannakis C, Bucheli CS, Skene KGM, Robinson SP, Scott NS (1998) Chitinase and $\beta$-1, 3-glucanase in grapevine leaves: a possible defence against powdery mildew infection. Aust J Grape Wine Res 4:14-22

Goetz G, Fkyerat A, Metais N, Kunz M, Tabacchi R, Pezet R, Pont V (1999) Resistance factors to grey mould in grape berries: identification of some phenolics inhibitors of Botrytis cinerea stilbene oxidase. Phytochemistry 52:759-767

González-Neves G, Gil G, Ferrer M (2002) Effect of different vineyard treatments on the phenolic contents in Tannat (Vitis vinifera L.) grapes and their respective wines. Food Sci Technol Int 8:315-321

Gryglewsk RJ, Korbut R, Robak J, Swies J (1987) On the mechanism of antithrombotic action of flavonoids. Biochem Pharmacol 36:317-322

Guebaila HA, Chira K, Richard T, Mabrouk T, Furiga A, Vitrac X, Monti JP, Delaunay JC, Merillon JM (2006) Hopeaphenol: the first resveratrol tetramer in wines from North Africa. J Agric Food Chem 54:9559-9564

Hakansson E, Pardon K, Hayasaka Y, de Sa M, Herderich M (2003) Structures and colour properties of new red wine pigments. Tetrahedron Lett 44:4887-4891

Hammerschmidt R, Smith-Becker JA (1999) The role of salicylic acid in disease resistance. In: Agarwal AA, Tuzum $\mathrm{S}$, Bent E (eds) Induced plant defenses against pathogens and herbivores. APS, St. Paul, pp 37-54

Hansen C (1995) Grape seed extract: procyanidolic oligmers (PCO). Healing Wisdom, New York

Hansen AS, Marckmann P, Dragsted LO, Finne-Nielsen IL, Nielsen SE, Gronbaek M (2005) Effect of red wine and red grape extract on blood lipids, haemostatic factors, and other risk factors for cardiovascular disease. Eur J Clin Nutr 59:449-455

Harborne JB (1999) The comparative biochemistry of phytoalexin induction in plants. Biochem Syst Ecol 27:335367

Harborne JB (2001) Twenty-five years of chemical ecology. Nat Prod Rep 18:361-379

Hayasaki Y, Adams KS, Pocock KF, Baldock GA, Waters EJ, Hoj PB (2001) Use of electrospray mass spectrometry for mass determination of grape (Vitis vinifera) juice pathogenesis-related proteins: a potential tool for varietal differentiation. J Agric Food Chem 49:1830-1839

Herbert P, Cabrita MJ, Ratola N, Laureano O, Alves A (2005) Free amino acids and biogenic amines in wines and musts from the Alentejo region. Evolution of amines during alcoholic fermentation and relationship with variety, subregion, and vintage. J Food Eng 66:315-322

Hernandez-Orte P, Cacho J, Ferreira V (2002) Relationship between varietal amino acid profile of grapes and wine aromatic composition. Experiments with model solutions and chemometric study. J Agric Food Chem 50:28912899

Hernandez-Orte P, Ibraz MJ, Cacho J, Ferriera V (2003) Amino acid determination in grape juices and wines by HPLC using a modification of the 6-aminoquinolyl-nhydroxysuccinimidyl carbamate (AQC) method. Chromatographia 58:29-35 
Hrazdina G, Parsons GF, Mattick LR (1984) Physiological and biochemical events during development and maturation of grape berries. Am J Enol Vitic 35:220-227

Iriti M, Faoro F (2006) Grape phytochemicals: a bouquet of old and new nutraceuticals for human health. Med Hypotheses 67:833-838

Iriti M, Rossoni M, Borgo M, Faoro F (2004) Benzothiadiazole enhances resveratrol and anthocyanin biosynthesis in grapevine, meanwhile improving resistance to Botrytis cinerea. J Agric Food Chem 52:4406-4413

Jackson RS (2000) Wine science: principles, practice, perception. Academic Press, California

Jacobs AK, Dry IB, Robinson SP (1999) Powdery mildew infection and ethephon treatment induce different pathogenesis-related cDNAs in grapevine. Plant Pathol 48:325336

Jang M, Cai L, Udeani GO, Slowing KV, Thomas CF, Beecher CWW, Fong HHS, Farnsworth NR, Hinghorn AD, Mehta RG, Moon RC, Pezzuto JM (1997) Cancer chemopreventive activity of resveratrol, a natural product derived from grapes. Science 275:218-220

Jean-Denis JB, Pezet R, Tabacchi R (2006) Rapid analysis of stilbenes and derivatives from downy mildew-infected grapevine leaves by liquid chromatography-atmospheric pressure photoionisation mass spectrometry. J Chromatogr A 112:263-268

Jeandet P, Bessis R, Gautheron B (1991) The production of resveratrol $(3,5,4$-trihydroxystilbene) by grape berries in different developmental stages. Am J Enol Vitic 42:41-46

Jeandet P, Bessis R, Sbaghi M, Meunier P (1995) Production of the phytoalexin resveratrol by grapes as a response to Botrytis attack under natural conditions. J Phytopathol 143:135-139

Jeandet P, Adrian M, Breuil AC, Sbaghi M, Debord S, Bessis R, Weston LA, Harmon R (2000) Chemical induction of phytoalexin synthesis in grapevines: application to the control of grey mould in the vineyard. Acta Hortic 528:591-596

Jeandet P, Douillet-Breuil AC, Bessis R, Debord S, Sbaghi M, Adrian M (2002) Phytoalexins from the Vitaceae: biosynthesis, phytoalexin gene expression in transgenic plants, antifungal activity, and metabolism. J Agric Food Chem 50:2731-2741

Kanner J, Frankel E, Granit R, German B, Kinsella JE (1994) Natural antioxidants in grapes and wines. J Agric Food Chem 42:64-69

Kaur G, Roberti M, Raul F, Pendurthi UR (2007) Suppression of human monocyte tissue factor induction by red wine phenolics and synthetic derivatives of resveratrol. Thromb Res 119:247-256

Keller M, Viret O, Cole M (2003) Botrytis cinerea infection in grape flowers: defense reaction, latency and disease expression. Phytopathology 93:316-322

Kennedy JA (2008) Grape and wine phenolics: observations and recent findings. Ciencia e Investigación Agraria 35:107-120

Khanna S, Roy S, Bagchi D, Bagchi M, Ken CK (2001) Upregulation of oxidant-induced VEGF expression in cultured keratinocytes by a grape seed proanthocyanidin extract. Free Radical Bio Med 31:38-42

Kikkert JR, Thomas MR, Reisch BI (2001) Grapevine genetic engineering. In: Roubelakis-Angelakis KA (ed) Molecular biology and biotechnology of the grapevine. Kluwer, Dordrecht, pp 393-463

Kobayashi S, Ishimaru M, Ding CK, Yakushiji H, Goto N (2001) Comparison of UDP-glucose: flavonoid 3-O-glucosyltransferase (UFGT) gene sequences between white grapes (Vitis vinifera) and their sports with red skin. Plant Sci 160:543-550

Kobayashi S, Ishimaru M, Hiraoka K, Honda C (2002) Myb related genes of the Kyoho grape (Vitis labruscana) regulate anthocyanin biosynthesis. Planta 215:924-933

Kourtis LK, Arvanitoyannis IS (2001) Implementation of hazard analysis critical control point (HACCP) system to the alcoholic beverages industry. Food Rev Int 17:1-44

Kraeva E, Tesniere C, Terrier N, Romieu C, Sauvage FX, Bierne J, Deloire A (1998) Transcription of a $\beta$-1, 3-glucanase gene in grape berries in a late developmental period, or earlier after wounding treatments. Vitis 37:107-111

Kuc J (1995) Phytoalexins, stress metabolism, and disease resistance in plants. Annu Rev Phytopathol 33:275-297

Landete JM, Polo L, Ferrer S, Pardo I (2005) Biogenic amines in wine from three Spanish regions. J Agric Food Chem 53:1119-1124

Langcake P (1981) Disease resistance of Vitis spp. and the production of the stress metabolites resveratrol, $\varepsilon$-viniferin, $\alpha$-viniferin and pterostilbene. Physiol Plant Pathol 18:213-226

Langcake P, Pryce RJ (1976) The production of resveratrol by Vitis vinifera and other members of the Vitaceae as a response to infection or injury. Physiol Plant Pathol 9:7786

Large PJ (1986) Degradation of organic nitrogen compounds by yeasts. Yeast 2:1-34

Lewinsohn E, Schalechet F, Wilkinson J, Matsui K, Tadmor Y, Nam K, Amar O, Lastochkin E, Larkov O, Ravid U, Hiatt W, Gepstein S, Pichersky E (2001) Enhanced levels of aroma and flavor compound S-linalool by metabolic engineering of terpenoid pathway in tomato fruits. Plant Physiol 127:1256-1265

Liviero L, Puglisi PP (1994) Antimutagenic activity of procyanidins from Vitis vinifera. Fitoterapia 63:203-209

Lodhi MA, Reisch BI (1995) In situ hybridization in Vitis vinifera L. Theor Appl Genet 90:11-16

Lu YR, Foo LY (1999) The polyphenol constituents of grape pomace. Food Chem 65:1-8

Madden LV, Ellis MA, Lalancette N, Hughes G, Wilson LL (2000) Evaluation of a disease warning system for downy mildew of grapes. Plant Dis 84:549-554

Mane C, Souquet JM, Olle D, Verries C, Veran F, Mazerolles G, Cheynier V, Fulcrand H (2007) Optimization of simultaneous flavanol, phenolic acid, and anthocyanin extraction from grapes using an experimental design: application to the characterization of Champagne grape varieties. J Agric Food Chem 55:7224-7233

Mangiapane H, Thomson J, Salter A, Brown S, Bell GD, White DA (1992) The inhibition of the oxidation of low density lipoprotein by (1)-catechin, a naturally occurring flavonoid. Biochem Pharmacol 43:445-450

Manthey JA, Buslig BS, Baker ME (2002) Flavonoids in cell function. Adv Exp Med Biol 505:1-7

Marcobal A, Martin-Alvarez PJ, Polo MC, Munoz R, MorenoArribas MV (2006) Formation of biogenic amines 
throughout the industrial manufacture of red wine. J Food Prot 69:391-396

Martelli GP (1993) Handbook for detection and diagnosis: grapevine degeneration Fanleaf. In: Martelli GP (ed) Graft transmissible diseases of grapevines. FAO, Rome, pp 9-18

Martelli GP, Savino V (1990) Fanleaf degeneration. In: Pearson R, Geheen AC (eds) Compendium of grape diseases. APS, St. Paul, pp 48-49

Mateus N, Oliveira J, Santos-Buelga C, Silva AMS, de Freitas VAP (2004) NMR structural characterization of a new vinylpyranoanthocyanin-catechin pigment (a portisin). Tetrahedron Lett 45:3455-3457

Matsumoto S, Shiraki K, Tsuji N, Hirata K, Miyamoto K, Takagi M (2004) Functional analysis of phytochelatin synthase from Arabidopsis thaliana and its expression in Escherichia coli and Saccharomyces cerevisiae. Sci Tech Adv Mat 5:377-381

Mattivi F, Guzzon R, Vrhovsek U, Stefanini M, Velasco R (2006) Metabolite profiling of grape: flavonols and anthocyanins. J Agric Food Chem 54:7692-7702

Mauro MC, Toutaina S, Pinck WL, Ottenc L, Coutos-Thevenotd P, Deloiree A, Barbierd P (1995) High efficiency regeneration of grapevine plants transformed with the GFLV coat protein gene. Plant Sci 112:97-106

Middleton E, Drzewieki G (1983) Flavonoid inhibition of human basophile histamine release stimulated by various agents. Biochem Pharmacol 33:3333-3338

Monagas M, Batolome B, Gomez-Cordoves C (2005) Update knowledge about the presence of phenolic compounds in wine. Crit Rev Food Sci Nutr 45:85-118

Monteiro S, Piçarra-Pereira MA, Teixeira AR, Loureiro VB, Ferreira RB (2003) Environmental conditions during vegetative growth determine the major proteins that accumulate in mature grapes. $J$ Agric Food Chem 51:4046-4053

Nakagawa H, Kiyozuka Y, Uemura Y, Senzaki H, Shikata N, Hioki K, Tsubura A (2001) Resveratrol inhibits human breast cancer cell growth and may mitigate the effect of linoleic acid, a potent breast cancer cell stimulator. J Cancer Res Clin 127:258-264

Naugler C, McCallum JL, Klassen G, Strommer J (2007) Concentrations of trans-resveratrol and related stilbenes in Nova Scotia wines. Am J Enol Vitic 58:117-119

Oliveira J, Santos-Buelga C, Silva AMS, de Freitas VAP, Mateus N (2006) Chromatic and structural features of blue anthocyanin-derived pigments present in Port wine. Anal Chim Acta 563:2-9

Owen KJ, Green CD, Deverall BJ (2002) A benzothiadiazole applied to foliage reduces development and egg deposition by Meloidogyne spp. in glasshouse-grown grapevine roots. Australas Plant Pathol 31:47-53

Pace-Asiak CR, Hahn SE, Diamandis EP, Soleas G, Goldberg DM (1995) The red wine phenolics trans-resveratrol and quercetin block human platelet aggregation and eicosanoid synthesis. Implications for protection against coronary heart disease. Clin Chem Acta 235:207-219

Packter NM (1980) Biosynthesis of acetate-derived phenols (polyketides). In: Stumpf PK (ed) The biochemistry of plants, vol 4. Academic Press, New York, pp 535-570
Patricia TA, Michel C, Guy V, Aziz A (2006) Chitosan stimulates defense reactions in grapevine leaves and inhibits development of Botrytis cinerea. Eur J Plant Pathol 114:405-413

Pearce F, Befus AD, Bienenstock J (1984) Mucosal mast cells, effects of quercetin and other flavonoids on antigeninduced histamine secretion from rat intestinal mast cells. J Allergy Clin Immunol 73:819-823

Peixe A, Hegewal H, Bohm J, Pais MS, Jacob AP (2004) Preliminary results of trials to improve fungal resistance in Portuguese Vitis vinifera cultivars using classical breeding approaches. Acta Hortic 652:315-319

Pellerin P, Vidal S, Williams P, Brillouet J (1995) Characterization of five type II arabinogalactan-protein complexes from red wine with increasing uronic acid content. Carbohydr Res 277:135-143

Pellerin P, Doco T, Vidal S, Williams P, Brillouet J, O’Neill M (1996) Structural characterization of red wine rhamnogalacturonan II. Carbohydr Res 190:183-197

Pena-Neira A, Hernandez T, Garcia-Vallejo C, Estrella I, Suarez JA (2000) A survey of phenolic compounds in Spanish wines of different geographic origin. Eur Food Res Technol 210:445-448

Pendurthi UR, Rao LVM (2002) Effect of wine phenolics and stilbene analogues on tissue factor expression in endothelial cells. Thromb Res 106:205-211

Pendurthi UR, Williams JT, Rao LVM (1999) Resveratrol, a polyphenolic compound found in wine, inhibits tissue factor expression in vascular cells. A possible mechanism for the cardiovascular benefits associated with moderate consumption of wine. Arterioscler Thromb Vasc Biol 19:419-426

Perrone G, Nocoletti I, Pascale M, De Rossi A, De Girolamo A, Visconti A (2007) Positive correlation between high levels of ochratoxin A and resveratrol-related compounds in red wines. J Agric Food Chem 55:6807-6812

Pezet R, Cuenat P (1996) Resveratrol in wine: extraction from skin during fermentation and post-fermentation standing of must from Gamay grapes. Am J Enol Vitic 47:287-290

Pezet R, Pont V (1990) Ultrastructural observations of Pterostilbene fungitoxicity in dormant conidia of Botrytis cinerea Pers. J Phytopathol 129:29-30

Pezet R, Perret C, Jean-Denis JB, Tabacchi R, Gindro K, Viret $\mathrm{O}$ (2003) $\delta$-Viniferin, a resveratrol dehydrodimer: one of the major stilbenes synthesized by stressed grapevine leaves. J Agric Food Chem 51:5488-5492

Pezet R, Gindro K, Viret O, Spring JL (2004) Glycosylation and oxidative dimerization of resveratrol are respectively associated to sensitivity and resistance of grapevine cultivars to downy mildew. Physiol Mol Plant Pathol 65:297-303

Poinssot B, Vandelle E, Bentejac M, Adrian M, Levis C, Brygoo Y, Garin J, Sicilia F, Coutos-Thevenot P, Pugin A (2003) The endopolygalacturonase-1 from Botrytis cinerea activates grapevine defense reactions unrelated to its enzymatic activity. Mol Plant Microbe Interact 16:553564

Pool RM, Creasy LL, Frackelton AS (1981) Resveratrol and the viniferins, their application to screening for disease resistance in grape breeding programs. Vitis 20:136-145 
Pozo-Bayon MA, Hernandez MT, Martin-Alvarez PJ, Polo MC (2003) Study of low molecular weight phenolic compounds during the aging of sparkling wines manufactured with red and white grape varieties. J Agric Food Chem 51:2089-2095

Pretorius IS (2000) Tailoring wine yeast for the new millennium: novel approaches to the ancient art of winemaking. Yeast 16:675-729

Pryce RJ, Langcake P (1977) $\alpha$-Viniferin: an antifungal resveratrol trimer from grapevines. Phytochemistry 16:14521454

Purkayashta RP (1995) Progress in phytoalexin research during the past 50 years. In: Daniel M, Purkayashta RP (eds) Handbook of phytoalexin metabolism and action. Marcel Dekker, New York, pp 1-39

Pussa T, Floren J, Kuldepp P, Raal A (2006) Survey of grapevine Vitis Vinifera stem polyphenols by liquid chromatography-diode array detection-tandem mass spectrometry. J Agric Food Chem 54:7488-7494

Rapp A, Mandery H (1986) Wine aroma. Experientia 42:873880

Rapp A, Versini G (1991) Influence of nitrogen compounds in grapes on aroma compounds of wines. In: Rantz J (ed) International symposium on nitrogen in grapes and wine. American Society for Enology and Viticulture, Davis, pp 156-164

Reglinski T, Elmer PAG, Taylor JT, Parry FJ, Marsden R, Wood PN (2005) Suppression of Botrytis bunch rot in Chardonnay grapevines by induction of host resistance and fungal antagonism. Australas Plant Pathol 34:481-488

Renault AS, Deloire A, Bierne J (1996) Pathogenesis-related proteins in grapevines induced by salicylic acid and Botrytis cinerea. Vitis 35:49-52

Repka V, Fischerova I, Silharova K (2004) Methyl jasmonate is a potent elicitor of multiple defense responses in grapevine leaves and cell-suspension cultures. Biol Plant 48:273-283

Ribereau-Gayon P, Glories Y, Maujean A, Dubourdieu D (2000) Handbook of enology, vol 2. Wiley, New York

Ricardo-Da-Silva JM, Cheynier V, Samson A, Bourzeix M (1993) Effect of pomace contact, carbonic maceration, and hyperoxidation on the procyanidin composition of Grenach Blanc wines. Am J Enol Vitic 44:168-172

Riou V, Vernhet A, Doco T, Moutounet M (2002) Aggregation of grape seed tanins in model wine-effect of wine polysaccharides. Food Hydrocoll 16:17-23

Robert N, Roche K, Lebeau Y, Breda C, Boulay M, Esnault R, Buffard D (2002) Expression of grapevine chitinase genes in berries and leaves infected by fungal or bacterial pathogens. Plant Sci 162:389-400

Robinson SP, Davies C (2000) Molecular biology of grape berry ripening. Aust J Grape Wine Res 6:175-188

Robinson SP, Jacobs AK, Dry IB (1997) A class IV chitinase is highly expressed in grape berries during ripening. Plant Physiol 114:771-778

Roggero JP, Garcia-Parrilla C (1995) Effects of ultraviolet irradiation on resveratrol and changes in resveratrol and various of its derivatives in the skins of ripening grapes. Sci Aliments 15:411-422

Romanazzi G, Nigro E, Ippolito A, Di-Venere D, Salerno M (2002) Effects of pre- and postharvest chitosan treatments to control storage grey mold of table grapes. J Food Sci 67:1862-1867

Rosslenbroich HJ, Stuebler D (2000) Botrytis cinerea-history of chemical control and novel fungicides for its management. Crop Prot 19:557-561

Saito M, Hosoyama H, Ariga T, Kataoka S, Yamaji N (1998) Antiulcer activity of grape seed extract and procyanidins. J Agric Food Chem 46:1460-1464

Sarig P, Zutkhi Y, Lisker N, Shkelerman Y, Ben-Arie R, Bielski R, Laing W, Clark C (1998) Natural and induced resistance of table grapes to bunch rots. Acta Hortic 464:65-70

Sato M, Maulik G, Ray PS, Bagchi D, Das DK (1999) Cardioprotective effects of grape seed proanthocyanidin against ischemic reperfusion injury. J Mol Cell Cardiol 31:1289-1297

Sato M, Bagchi D, Tosaki A, Das DK (2001) Grape seed proanthocyanidin reduces cardiomyocyte apoptosis by inhibiting ischemia/reperfusion-induced activation of JNK-1 and CJUN. Free Radical Bio Med 31:729-737

Sbaghi M, Jeandet P, Faivre B, Bessis R, Fournioux JC (1995) Development of methods using phytoalexin (resveratrol) assessment as a selection criterion to screen grapevine in vitro cultures for resistance to grey mould (Botrytis cinerea). Euphytica 86:41-47

Schneider Y, Chabert P, Stutzmann J, Coelho D, Fougerousse A, Gosse F, Launay JF, Brouillard R, Raul F (2003) Resveratrol analog (Z)-3, 5, 4'-tri-methoxystilbene is apotent anti mitotic drug inhibiting tubulin polymerization. Int J Cancer 107:189-196

Schneider Y, Fischer B, Coelho D, Roussi S, Gosse F, Pierre B, Raul F (2004) (Z)-3, 5, 4'-tri-O-methyl-resveratrol, induces apoptosis in human lymphoblastoid cells independently of their p53 status. Cancer Lett 211:155-161

Schoefer L, Braune A, Blaut M (2001) A fluorescence quenching test for the detection of flavonoid transformation. FEMS Microbiol Lett 204:277-280

Schwarz M, Jerz G, Winterhalter P (2003) Isolation and structure of Pinotin A, a new anthocyanin derivative from Pinotage wine. Vitis 42:105-106

Shi J, Yu J, Pohorly JE, Kakuda Y (2003) Polyphenolics in grape seeds-biochemistry and functionality. J Med Food 6:291-299

Silva RC, Darmon N, Fernandez Y, Mitjavila S (1991) Oxygen free radical scavenger capacity in aqueous models of different procyanidins from grape seeds. J Agric Food Chem 39:1549-1552

Singleton VL (1982) Grape and wine phenolics; background and prospects. In: Webb AD (ed) Proceedings of the University of California, Davis, Grape and Wine Centennial Symposium. University of California Press, Davis, pp 215-227

Sladkovsky R, Solich P, Urbanek M (2004) High performance liquid chromatography determination of phenolic compounds in wine using off-line isotachophoretic pre-treatment. J Chromatogr A 1040:179-184

Soleas GJ, Goldberg DM, Grass L, Levesque M, Diamandis EP (2001) Do wine polyphenols modulate p53 gene expression in human cancer lines? Clin Biochem 34:415420

Sovak M (2001) Grape extract, resveratrol, and its analogs: a review. J Med Food 4:93-105 
Sponholz WR (1988) Alcohols derived from sugars and other sources and fullbodiedness of wines. In: Liskens JF, Jackson JF (eds) Wine analysis. Springer, Berlin, pp 147-172

Stervbo U, Vang O, Bonnesen C (2007) A review of the content of putative chemopreventive phytoalexin resveratrol in red wine. Food Chem 101:449-457

Sun B, Spranger MI (2005) Quantitative extraction and analysis of grape and wine proanthocyanidins and stilbenes. Ciencia e Tecnica Vitivinicola 20:59-89

Sun BS, Ferrão C, Spranger MI (2003) Effect of wine style and winemaking technology on resveratrol level in wines. Ciencia e Tecnica Vitivinicola 18:77-91

Sun BS, Ribes A, Leandro MC, Belchior AP, Spranger MI (2006) Stilbenes: quantitative extraction from grape skins, contribution of grape solids to wine and variation during wine maturation. Anal Chim Acta 563:382-390

Talcott S, Lee J (2002) Ellagic acid and flavonoid antioxidant content of muscadine wine and juice. J Agric Food Chem 50:3186-3192

Tattersall DB, van Heeswijck R, Hoj PB (1997) Identification and characterization of a fruit-specific, thaumatin-like protein that accumulates at very high levels in conjunction with the onset of sugar accumulation and berry softening in grapes. Plant Physiol 114:759-769

Tebib K, Besancon P, Rouanet J (1996) Effects of dietary grape seed tannins on rat cecal fermentation and colonic bacterial enzymes. Nutr Res 16:105-110

Tedesco I, Russo M, Russo P, Iacomino G, Russo GL, Carraturo A, Faruolo C, Moio L, Palumbo R (2000) Antioxidant effect of red wine polyphenols on red blood cells. J Nutr Biochem 11:114-119

Teissedre PL, Frankel EN, Waterhouse AL, Peleg H, German JB (1996) Inhibition of in vitro human LDL oxidation by phenolic antioxidants from grapes and wines. J Sci Food Agric 70:55-61

This P, Lacombe T, Thomas MR (2006) Historical origins and genetic diversity of wine grapes. Trends Genet 22:511519

Thomas MR, Matsumoto S, Cain P, Scott NS (1993) Repetitive DNA of grapevine: classes present and sequences suitable for cultivar identification. Theor Appl Genet 86:173-180

Tsvetkov IJ, Atanassov AI, Tsolova VM (2000) Gene transfer for stress resistance in grapes. Acta Hortic 528:389-396

Tyagi A, Agarwal R, Agarwal C (2003) Grape seed extract inhibits EGF-induced and constitutively active mitogenic signaling but activates JNK in human prostate carcinoma DU145 cells: possible role in antiproliferation and apoptosis. Oncogene 22:1302-1316

Uchida S (1980) Condensed tannins scavenging active oxygen radicals. Med Sci Res 15:831-832

Vanhoenacker G, De Villiers A, Lazou K, Keukeleire D, Sandra P (2001) Comparison of high performance liquid chromatography-mass spectroscopy and capillary electrophoresis-mass spectroscopy for the analysis of phenolic compounds in diethyl ether extracts of red wines. Chromatographia 54:309-315

Vezzulli S, Civardi S, Ferrari F, Bavaresco L (2007) Methyl jasmonate treatment as a trigger of resveratrol synthesis in cultivated grapevine. Am J Enol Vitic 58:530-533

Vidal S, Doco T, Williams P, Pellerin P, York WS, O'Neill MA, Glushka J, Darvill AG, Albersheim P (2000) Structural characterization of the pectic polysaccharide rhamnogalacturonan II: evidence for the backbone location of the aceric acid containing oligoglycosyl side chain. Carbohydr Res 326:277-294

Vidal S, Hayasaka Y, Meudec E, Cheynier V, Skouroumounis G (2004) Fractionation of grape anthocyanin classes using multilayer coil countercurrent chromatography with step gradient elution. J Agric Food Chem 52:713-719

Vidal JR, Kikkert JR, Malnoy MA, Wallace PG, Barnard J, Reisch BI (2006) Evaluation of transgenic 'Chardonnay' (Vitis vinifera) containing magainin genes for resistance to crown gall and powdery mildew. Transgenic Res 15: $69-82$

Vitrac X, Bornet A, Vanderlinde R, Valls J, Richard T, Delaunay J-C, Merillon J-M, Teissedre P-L (2005) Determination of stilbenes ( $\delta$-viniferin, trans-astringin, transpiceid, cis- and trans-resveratrol, $\varepsilon$-viniferin) in Brazilian wines. J Agric Food Chem 53:5664-5669

Vivier MA, Pretorius IS (2000) Genetic improvement of grapevine: tailoring grape varieties for the third millennium. S Afr J Enol Vitic 21:5-26

Vivier MA, Pretorius IS (2002) Genetically tailored grapevines for the wine industry. Trends Biotechnol 20:472-488

Vogels N, Nijs IMT, Westerterp-Plantenga MS (2004) The effect of grape seed extract on $24 \mathrm{~h}$ energy intake in humans. Eur J Clin Nutr 58:667-673

Wallace CHR, Baczko I, Jones L, Fercho M, Light PE (2006) Inhibition of cardian voltage-gated sodium channels by grape polyphenols. Br J Pharmacol 149:657-665

Waters EJ, Hayasaka Y, Tattersall DB, Adams KS, Williams PJ (1998) Sequence analysis of grape (Vitis vinifera) berry chitinases that cause haze formation in wines. J Agric Food Chem 46:4950-4957

Williams AA, Rosser PR (1981) Aroma enhancing effects of ethanol. Chem Senses 6:149-153

Yamamoto T, Iketani H, Ieki H, Nishizawa Y, Notsuka K, Hibi T, Hayashi T, Matsuta N (2000) Transgenic grapevine plants expressing a rice chitinase with enhanced resistance to fungal pathogens. Plant Cell Rep 19:639-646

Yilmaz Y, Toledo RT (2004) Health aspects of functional grape seed constituents. Trends Food Sci Tech 15:422433

Zhang L, Kai G, Lu B, Zhang H, Tang K, Jiang J, Chen W (2005) Metabolic engineering of tropane alkaloid biosynthesis in plants. J Integr Plant Biotechnol 47:136-143 